\title{
Chemical weathering and carbon dioxide consumption in a small tropical river catchment, southwestern India
}

\author{
Baby Krishnan Nisha ${ }^{1} \cdot$ Keshava Balakrishna $^{1}$ (D) Harikripa Narayana Udayashankar ${ }^{1}$. \\ Busnur Rachotappa Manjunatha ${ }^{2}$
}

Received: 5 December 2020 / Accepted: 13 April 2021 / Published online: 28 April 2021

(c) The Author(s) 2021

\begin{abstract}
Studies done on small tropical west-flowing river catchments located in the Western Ghats in southwestern India have suggested very intense chemical weathering rates and associated $\mathrm{CO}_{2}$ consumption. Very less studies are reported from these catchments notwithstanding their importance as potential sinks of atmospheric $\mathrm{CO}_{2}$ at the global scale. A total of 156 samples were collected from a small river catchment in the southwestern India, the Payaswini-Chandragiri river Basin, during pre-monsoon, monsoon and post-monsoon seasons in 2016 and 2017, respectively. This river system comprises two small rivers originating at an elevation of $1350 \mathrm{~m}$ in the Western Ghats in peninsular India. The catchment area is dominated by biotite sillimanite gneiss. Sodium is the dominant cation, contributing $50 \%$ of the total cations, whereas $\mathrm{HCO}_{3}{ }^{-}$contributes $\sim 75 \%$ of total anions. The average anion concentration in the samples varied in the range $\mathrm{HCO}_{3}{ }^{-}>\mathrm{Cl}^{-}>\mathrm{SO}_{4}{ }^{2-}>\mathrm{NO}_{3}{ }^{-}>\mathrm{F}^{-}$, whereas major cation concentration varied in the range $\mathrm{Na}^{+}>\mathrm{Ca}^{2+}>\mathrm{Mg}^{2+}>\mathrm{K}^{+}$. The average silicate weathering rate (SWR) was $42 \mathrm{t} \mathrm{km}^{-2} \mathrm{y}^{-1}$ in the year 2016 and $36 \mathrm{t} \mathrm{km}^{-2} \mathrm{y}^{-1}$ in 2017. The average annual carbon dioxide consumption rate (CCR) due to silicate rock weathering was $9.6 \times 10^{5} \mathrm{~mol} \mathrm{~km}^{-2} \mathrm{y}^{-1}$ and $8.3 \times 10^{5} \mathrm{~mol} \mathrm{~km}^{-2} \mathrm{y}^{-1}$ for 2016 and 2017 , respectively. The CCR in the study area is higher than other large tropical river catchments like Amazon, Congo-Zaire, Orinoco, Parana and Indus because of its unique topography, hot and humid climate and intense rainfall.
\end{abstract}

Keywords Tropical river system $\cdot$ Water geochemistry $\cdot$ Silicate weathering rate $\cdot$ Atmospheric $\mathrm{CO}_{2}$ consumption $\cdot$ Southwest coast of India

Keshava Balakrishna

k.balakrishna@manipal.edu

1 Department of Civil Engineering, Manipal Institute of Technology, Manipal Academy of Higher Education, Manipal 576104, India

2 Department of Marine Geology, Mangalore University, Mangalagangothri 574199, India 


\section{Introduction}

The chemical composition of rivers is derived from diverse sources like weathering of catchment rocks and soils, atmospheric deposition and anthropogenic discharges. In unpolluted river waters, lithological characteristics (source rock abundance) dominantly affect the concentration of major ions and trace elements (Gaillardet et al. 1999). In a hot and humid tropical setup, chemical weathering predominates over physical weathering, which has a bearing on the long-term global climate change.

Chemical weathering of a terrain plays a key role in the atmospheric $\mathrm{CO}_{2}$ consumption. The chemical weathering of a silicate rock converts the atmospheric $\mathrm{CO}_{2}$ into dissolved inorganic carbon and deposits in the form of carbonic sediments in the ocean (Berner 1991) as noted in

$$
\begin{aligned}
& \mathrm{CaSiO}_{3}+2 \mathrm{CO}_{2}+\mathrm{H}_{2} \mathrm{O} \rightarrow \mathrm{Ca}^{2+}+2 \mathrm{HCO}_{3}^{-}+\mathrm{SiO}_{2} \\
& \mathrm{Ca}^{2+}+2 \mathrm{HCO}_{3} \rightarrow \mathrm{CaCO}_{3} \downarrow+\mathrm{H}_{2} \mathrm{O}+\mathrm{CO}_{2} \uparrow
\end{aligned}
$$

There are several factors affecting the rate of chemical weathering, such as the geology of the terrain (rock type), topography (relief), soil cover, discharge, temperature and precipitation (Gaillardet et al. 1999; Huh 2003; Millot et al. 2002, 2003; Oliva et al. 2003; Guo and Wang 2005; Andersson et al. 2006; Moon et al. 2007). Studies were carried out across the world to estimate the chemical weathering rate and CCR of the major world rivers in the past decades, notably Amazon (Stallard and Edmond 1983), Ganges-Brahmaputra (Sarin et al. 1989), Yellow (Zhang et al. 1995), Nile (Dekov et al. 1997), Indus (Ahmad et al. 1998), Mississippi (Sharif et al. 2008), Mekong (Huang et al. 2009), Tigris (Varol et al. 2013), Yangtze (Huang et al. 2009; Jiang et al. 2015), Netravathi (Gurumurthy et al. 2012), Kavery (Pattanaik et al. 2013) and Brahmaputra (Das et al. 2016).

Tropical rivers are the largest carriers of dissolved and sediment load to the world's oceans and significantly influence the biogeochemical cycles of elements. Limited studies are done on the tropical systems worldwide, because of their location in the developing and underdeveloped countries. Meybeck (1987) emphasized the importance of tropical ecosystems and the paucity of data on these systems, though they are responsible for contributing $50 \%$ of water, $38 \%$ of dissolved ions and $68 \%$ of dissolved silica into the global oceans. The objectives of the present study are to partially fill the paucity in data from the tropical systems. Samples were collected from the tropical Payaswini-Chandragiri river basin, southwest coast of India during pre-monsoon, monsoon and post-monsoon in 2016 and 2017. Currently, no studies have been reported on the major ion chemistry of this river system. This river system is the biggest in northern Kerala state among the 13 river systems draining silicate-rich rock terrains. This study investigated the presence, distribution and source of major ions in the southwest-flowing river and estimated the SWR and associated CCR using the forward model (Wu et al. 2008). These data will add to the database of global silicate weathering rates of world rivers and filling the gaps existing on the silicate weathering and CCR in Indian tropical rivers. 


\section{Materials and methods}

\subsection{Study area}

The Chandragiri-Payaswini river system (area $1406 \mathrm{~km}^{2}$ and length $105 \mathrm{~km}$ ) is located along the southwest coast of peninsular India originating in the Western Ghats. Geographically the study area lies between $74^{\circ} 48^{\prime} \mathrm{E}$ and $75^{\circ} 45^{\prime} \mathrm{E}$ and $12^{\circ} 18^{\prime} \mathrm{N}$ and $12^{\circ} 32^{\prime} \mathrm{N}$ longitudes and latitudes, respectively. These rivers originate at an altitude of about $1350 \mathrm{~m}$ above mean sea level (MSL) and join the Arabian sea near Kasaragod town (Fig. 1).

Geologically, the basement of the study area belongs to the Archean metamorphics (Fig. 1). The main rock types are granite biotite sillimanite gneiss, charnockite, schist and dolerite. Charnockites, hornblende-biotite gneiss and high-grade schistose rocks are extensively lateritized in the lower reaches and dominate the drainage basin of Chandragiri river. There are no reports of the presence of carbonates/evaporates. The study area experiences typical tropical climate with hot $\left(20^{\circ}-38^{\circ} \mathrm{C}\right)$ and humid conditions $(4,000 \mathrm{~mm}$ annual rainfall), high surface runoff ( $2715 \mathrm{~mm}$ for entire west-flowing river catchment) with an annual water discharge of $4.40 \mathrm{~km}^{3} /$ year (Reddy et al. 2019) (Fig. S1).

Anthropogenic activities are minimal in the area, though two plywood industries located near Sullia town, on the banks of Payaswini River, and hospital discharge outlet near Aleti are discharging their effluents into the river (Fig. 1). Kasaragod municipal wastewater is discharged directly into the river estuary.

\subsection{Sampling and analysis}

Twenty-six river water samples were collected in each season, from the mainstream and tributaries (Fig. 1) during pre-monsoon (April), monsoon (August) and post-monsoon (December) seasons for a period of 2 years $(2016,2017)$. A total of 156 samples were collected in six seasons. Water samples were collected from road bridges such that samples are received from the center of the river and in the well-mixed condition. A polypropylene (PP) bucket tied with Nylon rope was dropped to the river for the sample collection. $\mathrm{pH}$, temperature, electric conductivity (EC) and dissolved oxygen (DO) were measured on-site using $\mathrm{HACH}$-make portable multiparameter, calibrated with the standard solution.
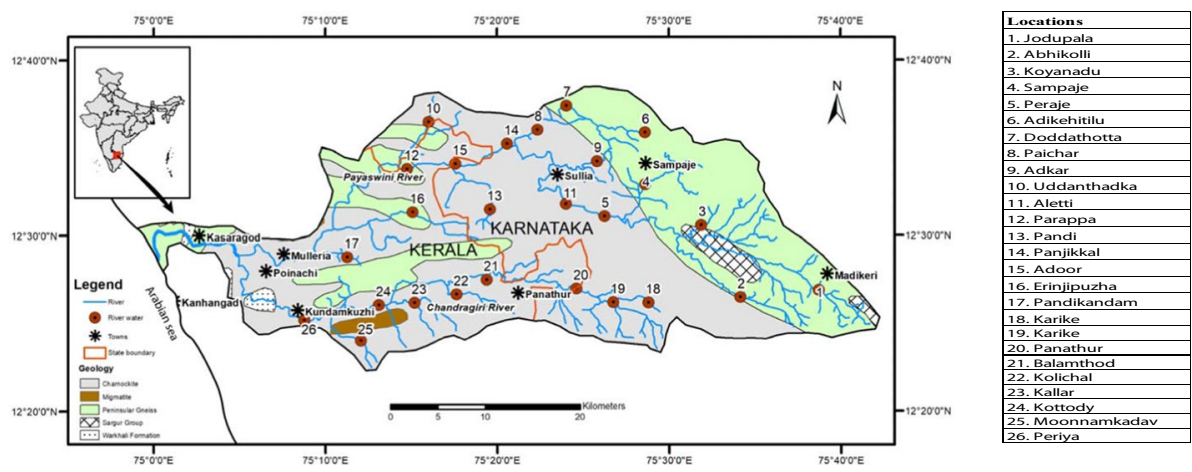

Fig. 1 Geological map of Payaswini-Chandragiri river basin with sampling locations ( source of the data; 1:20 K geological map of India) 
The samples were stored in pre-cleaned PP-grade bottles $(1000 \mathrm{ml})$. Water samples were filtered through $0.22-\mu \mathrm{m}$ pore size, $47-\mathrm{mm}$-diameter Nuclepore polycarbonate filters using a Sartorius-make membrane filtration apparatus in a laminar flow bench and stored at $4{ }^{\circ} \mathrm{C}$ for further analysis. The filtered water samples were analyzed for major ions using DIONEX-1100 ion chromatography with autosampler having separate cation-anion suppressor and column system. Accuracy of the results was checked with a known concentration of the standard solutions, which were within $\pm \_5 \%$. Precision of the results was checked with duplicate samples, which were within $\pm 3 \%$ (Table S1). Alkalinity of the samples was measured using the standardized $\mathrm{HCl}$ titration method using an autotitrator (METROHM TIAMO). Since the $\mathrm{pH}$ of all the samples is less than 8.3, the carbonate alkalinity was nonexistent. The end point of bicarbonate alkalinity ranged from 4.8 to 5.5 (Fig. $\mathrm{S} 2)$, with $\pm 2 \%$ accuracy and precision. Dissolved silica $\left(\mathrm{SiO}_{2}\right)$ in the river water samples was measured through the UV-Vis spectrometer, HACH DR 5000 by silicon molybdate method at $452 \mathrm{~nm}$ wavelengths with a precision of $\pm 2 \%$. Normalized inorganic charge balance (NICB) was calculated between total dissolved cations $\left(\mathrm{TZ}^{+}\right)$and total dissolved anions $\left(\mathrm{TZ}^{-}\right)$, and the charge balance was within $\pm 15 \%$ (Fig. 2 ). Above $10 \%$ of NICB values of the samples could be due to the presence of organic anions and cations.

\section{Result and discussion}

\subsection{Hydrogeochemistry}

The physiochemical composition of the Payaswini-Chandragiri river water is tabulated in Table 1 . The $\mathrm{pH}$ of the river was slightly alkaline in nature and showed a small variation seasonally (6.1-8.3) and spatially. In monsoon season, the average $\mathrm{pH}$ was lower than the rest of the seasons, because of the mixing of rain water, which has typical $\mathrm{pH}$ of 5.5.

The electric conductivity of the river samples varied from 31 to $176 \mu \mathrm{S} / \mathrm{cm}$ in pre-monsoon, $49-93 \mu \mathrm{S} / \mathrm{cm}$ in monsoon and $31-83 \mu \mathrm{S} / \mathrm{cm}$ in post-monsoons. Total dissolved solid of the samples was calculated from the concentration of obtained major ions and silica. The concentration of TDS in the pre-monsoon varied from 29 to $112 \mathrm{mg} / \mathrm{l}, 36-80 \mathrm{mg} / \mathrm{l}$ in monsoon and 29-84 mg/l in post-monsoon, respectively. The average TDS of Payaswini-Chandragiri river $(60 \mathrm{mg} / \mathrm{l})$ is less than the world's major rivers (Gaillardet et al.

Fig. 2 Correlation between total anion and total cation

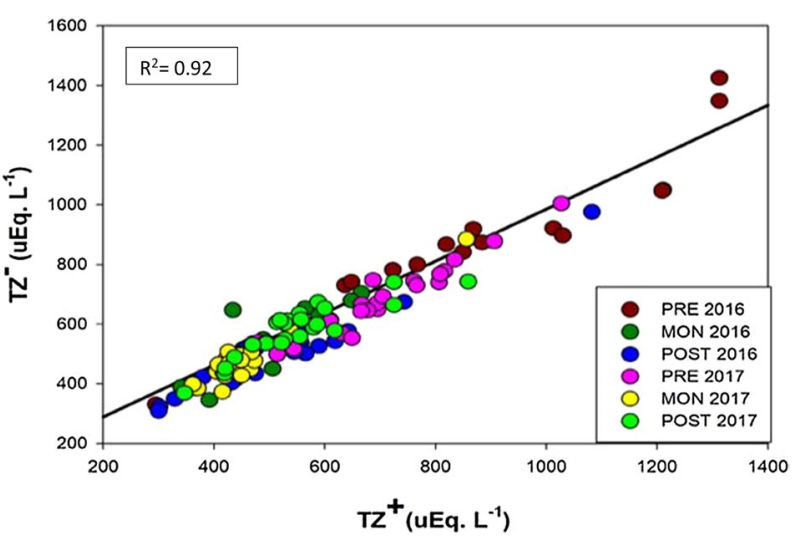




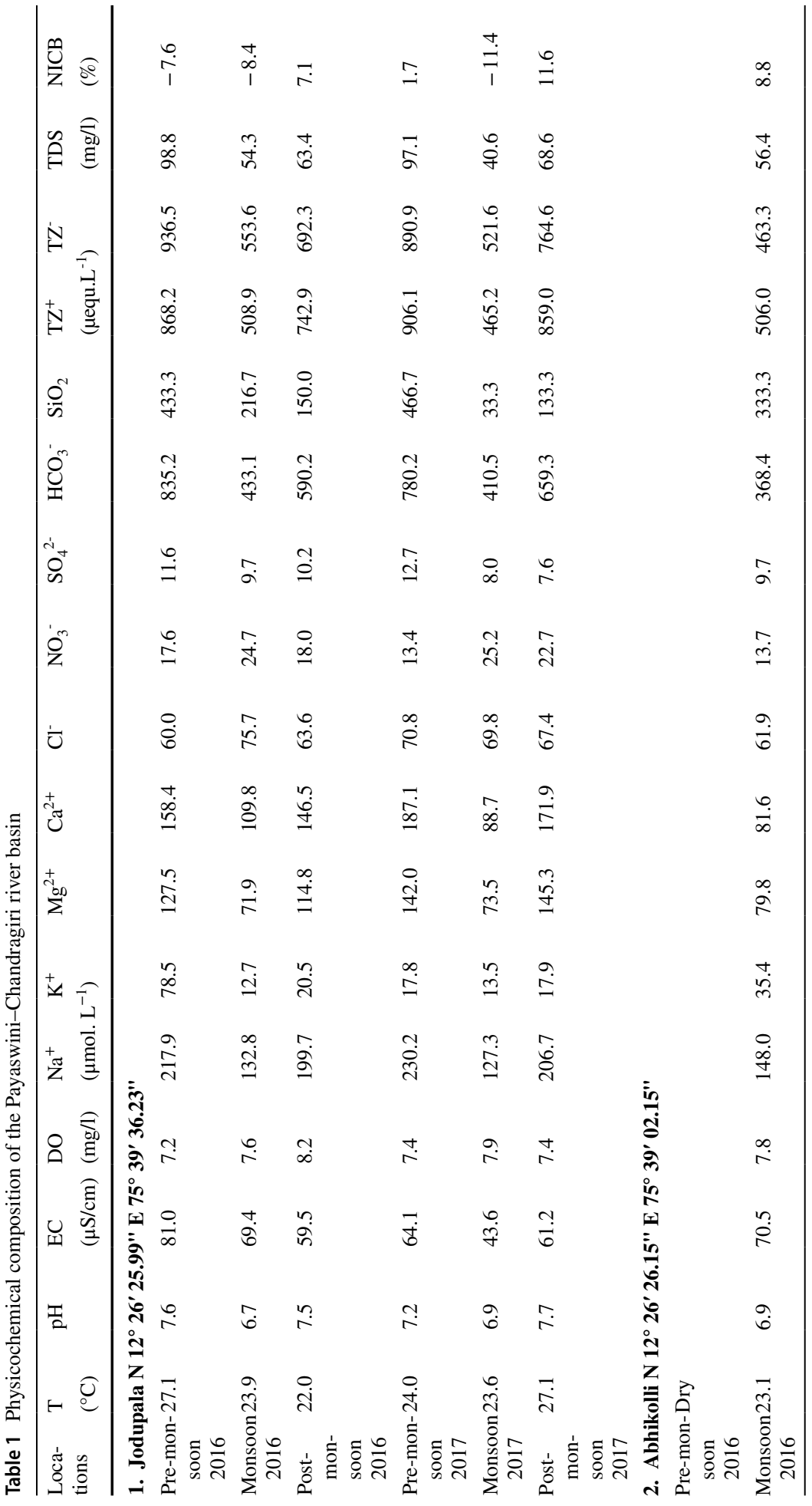




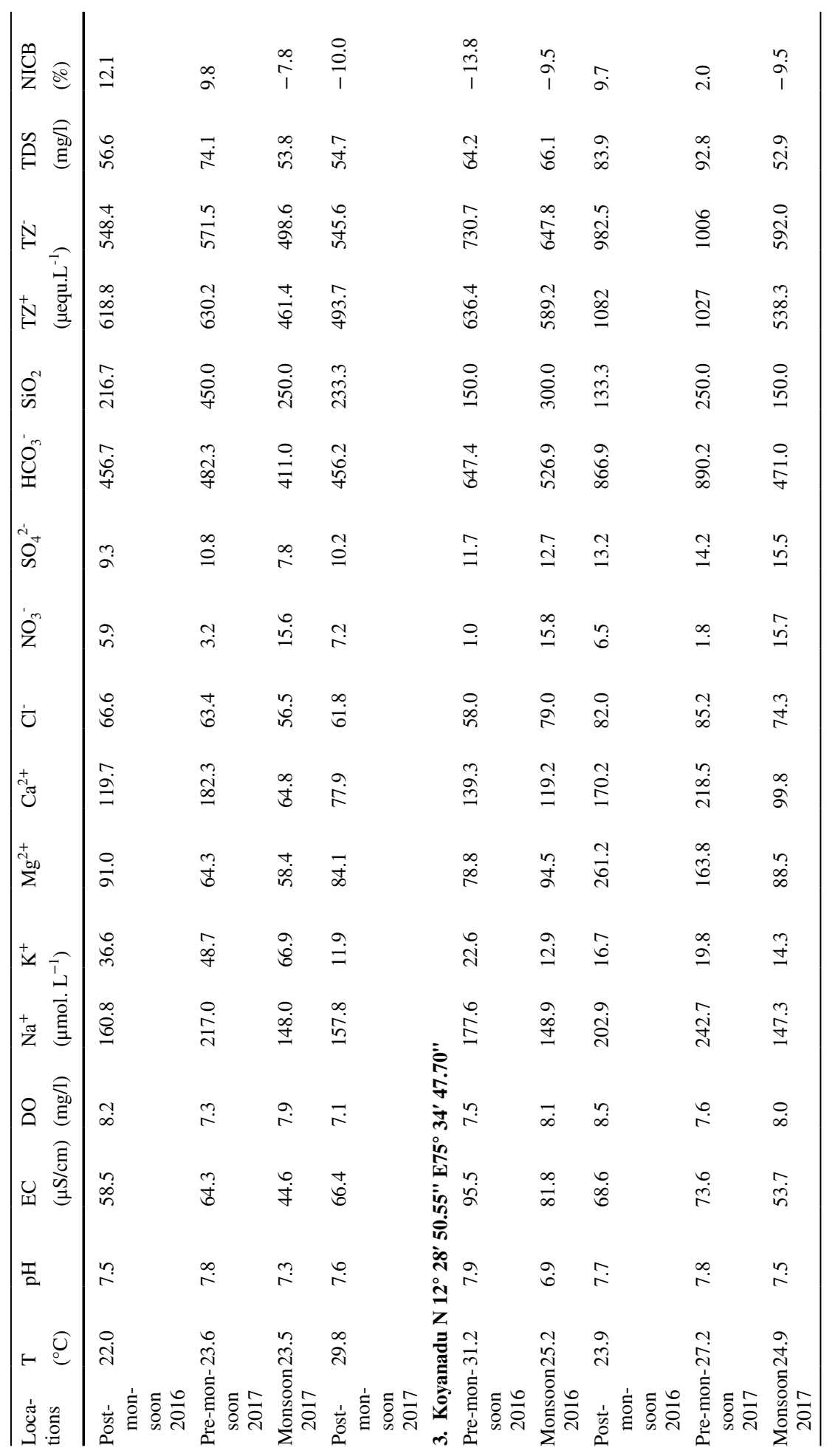




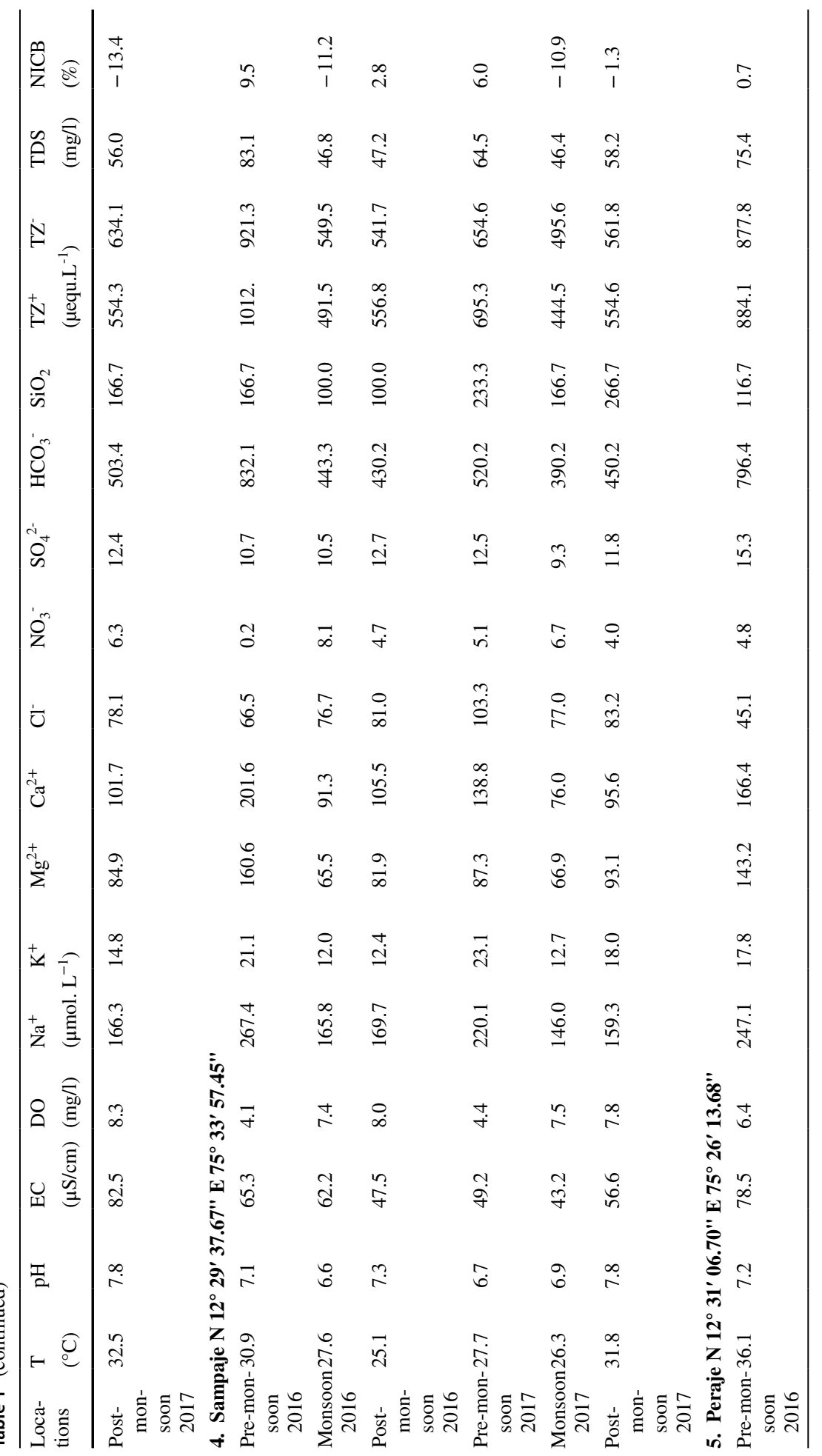




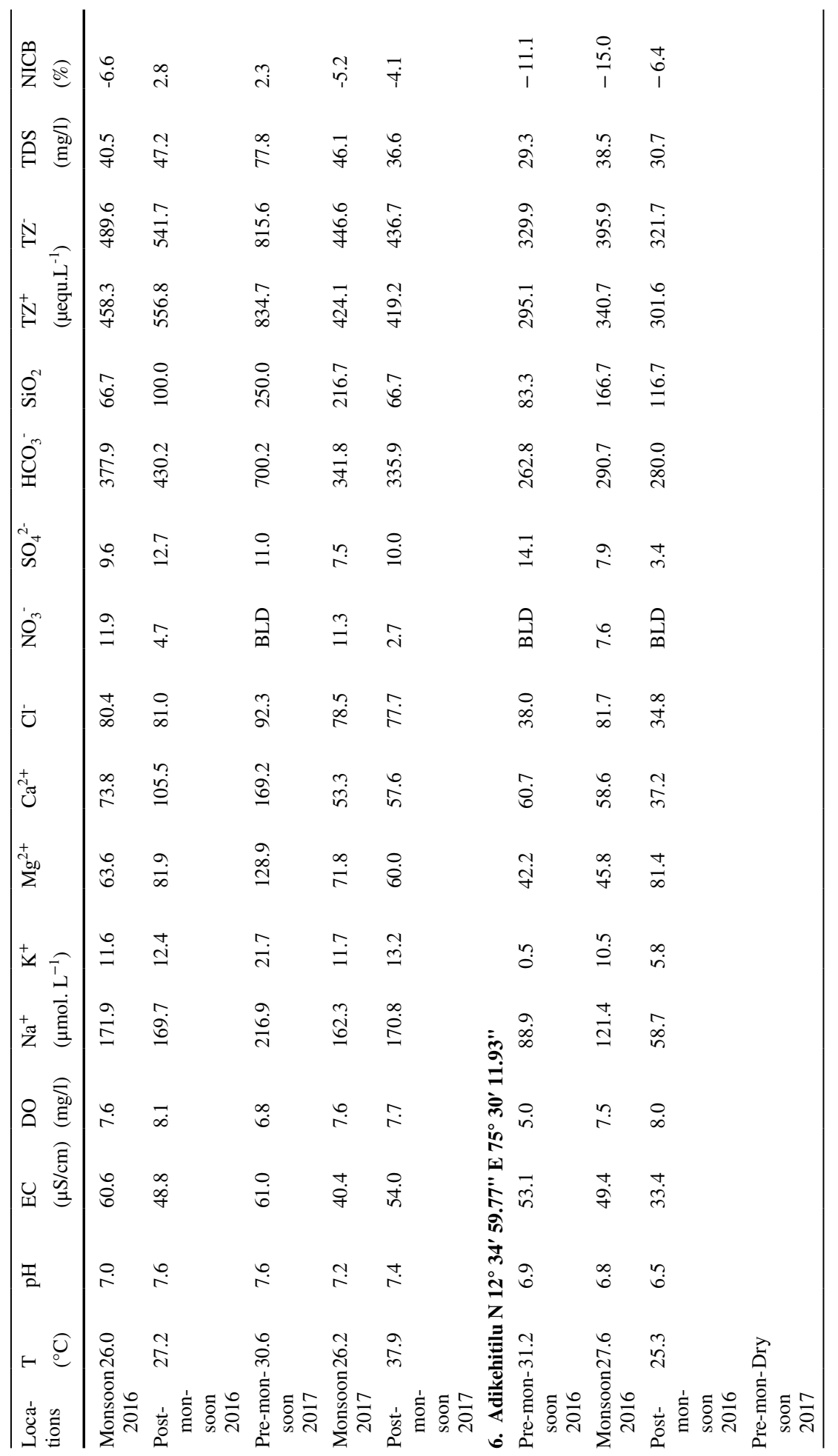




\begin{tabular}{|c|c|c|c|c|c|c|c|c|}
\hline 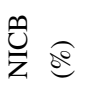 & $\begin{array}{l}\stackrel{i}{i} \\
i\end{array}$ & $\hat{b}$ & $\begin{array}{l}\stackrel{\infty}{\oplus} \\
\stackrel{-}{-}\end{array}$ & $\stackrel{\infty}{0}$ & $\stackrel{\infty}{\stackrel{\infty}{+}}$ & $\stackrel{\Xi}{\leftrightarrows}$ & $\underset{+}{\stackrel{+}{ \pm}}$ & $\stackrel{m}{m}_{1}$ \\
\hline 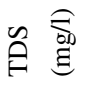 & $\overrightarrow{\text { mे }}$ & $\underset{m}{\stackrel{0}{m}}$ & $\overrightarrow{8}$ & 审 & $\ddot{\text { ते }}$ & $\stackrel{\vec{r}}{\dot{f}}$ & $\begin{array}{l}\vec{\phi} \\
\dot{\infty}\end{array}$ & $\vec{y}$ \\
\hline$\stackrel{+}{\ominus} \bumpeq$ & 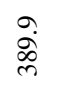 & $\underset{i}{\stackrel{i}{n}}$ & 苑 & $\hat{i}$ & $\frac{\vec{n}}{m}$ & $\frac{7}{5}$ & $\begin{array}{l}0 \\
\stackrel{\infty}{F} \\
\forall\end{array}$ & $\begin{array}{l}\stackrel{0}{0} \\
\stackrel{+}{q}\end{array}$ \\
\hline 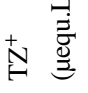 & $\underset{m}{\stackrel{\infty}{\infty}}$ & $\begin{array}{l}\infty \\
\stackrel{0}{0} \\
\text { m. }\end{array}$ & $\stackrel{\stackrel{ }{\mathrm{I}}}{\mathrm{I}}$ & $\begin{array}{l}\stackrel{0}{-} \\
\text { के }\end{array}$ & ֶ̊. & $\stackrel{\circ}{\dot{+}}$ & $\begin{array}{l}\text { त्र } \\
\text { ర్ల }\end{array}$ & 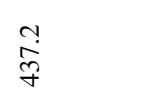 \\
\hline 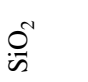 & $\hat{\theta}$ & $\stackrel{0}{8}$ & $\underset{\vec{\sigma}}{\vec{\sigma}}$ & $\stackrel{\vec{\sigma}}{\sim}$ & $\stackrel{\check{0}}{\circ}$ & $\stackrel{\check{\sigma}}{=}$ & $\begin{array}{l}\stackrel{\circ}{\dot{n}} \\
\stackrel{n}{n}\end{array}$ & $\stackrel{m}{m}$ \\
\hline$\overbrace{0}^{m}$ & ஜें & 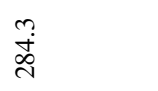 & $\frac{n}{n}$ & $\begin{array}{l}\hat{\sigma} \\
\vec{\sim}\end{array}$ & $\begin{array}{l}\stackrel{0}{0} \\
\stackrel{\oplus}{1}\end{array}$ & $\begin{array}{c}n \\
\infty \\
\infty \\
n\end{array}$ & $\begin{array}{l}0 \\
\stackrel{0}{0} \\
\stackrel{0}{1}\end{array}$ & $\underset{\infty}{+\infty}$ \\
\hline$\overbrace{}^{+}$ & $n$ & $\stackrel{\circ}{r}$ & $\stackrel{\circ}{\stackrel{0}{ }}$ & $\stackrel{m}{=}$ & $\hat{\jmath}$ & $\grave{\varrho}$ & 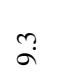 & $\vec{a}$ \\
\hline$\stackrel{m}{m}^{m}$ & $\begin{array}{l}\infty \\
\dot{n}\end{array}$ & $\begin{array}{l}0 \\
i\end{array}$ & $\stackrel{\forall}{+}$ & $\stackrel{\infty}{\stackrel{\sim}{\sim}}$ & ?ִ. & $\begin{array}{l}0 \\
\infty\end{array}$ & $\overrightarrow{\mathrm{d}}$ & $\stackrel{+}{\Xi}$ \\
\hline$\dot{U}$ & $\vec{i}$ & $\begin{array}{l}\infty \\
\dot{0}\end{array}$ & $\stackrel{\circ}{\dot{q}}$ & $\begin{array}{l}n \\
\stackrel{2}{0}\end{array}$ & $\ddot{n}$ & $\stackrel{+}{\dot{\circ}}$ & ?. & $\stackrel{\Upsilon}{\sigma}$ \\
\hline ت্ & ڤें & 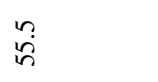 & $\vec{m}$ & $\stackrel{i}{i}$ & $\stackrel{\stackrel{y}{y}}{\mathscr{y}}$ & $\stackrel{\grave{a}}{\infty}$ & $\begin{array}{l}\infty \\
\infty \\
\infty\end{array}$ & $\stackrel{\infty}{i}$ \\
\hline$\sum^{+\infty}$ & $\stackrel{\sim}{g}$ & $\frac{a}{\vec{\gamma}}$ & $\begin{array}{l}n \\
\dot{\infty} \\
-\end{array}$ & $\stackrel{\circ}{\circ}$ & ị & $\ddot{n}$ & $\ddot{q}$ & $\stackrel{m}{n}$ \\
\hline \pm & $\stackrel{+}{\bullet}$ & $\ddot{n}$ & $\dddot{2}$ & $\stackrel{\infty}{\dot{ \pm}}$ & ๙̃ & ڤે̀े & $\stackrel{\Xi}{\mathrm{I}}$ & iें \\
\hline 塔 & 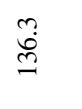 & ت̊. & 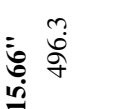 & $\stackrel{m}{m}$ & $\begin{array}{l}\dot{0} \\
\dot{0} \\
\stackrel{\sigma}{0}\end{array}$ & $\overrightarrow{8}$ & r̊ & $\frac{n}{n}$ \\
\hline ڤ̊ & $\stackrel{i}{i}$ & $\stackrel{9}{r}$ & $\begin{array}{l}i \\
i \\
i n \\
\text { in }\end{array}$ & $\stackrel{⿱ 亠 凶}{r}$ & $\stackrel{0}{\infty}$ & $\stackrel{\infty}{\emptyset}$ & $\stackrel{+}{r}$ & $\stackrel{0}{\infty}$ \\
\hline 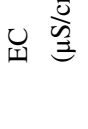 & $\underset{m}{\ddot{m}}$ & ळे & $\begin{array}{l}\dot{\partial} \\
\dot{m} \\
\text { men } \\
\text { in }\end{array}$ & $\stackrel{\overbrace{}}{6}$ & $\stackrel{\infty}{\stackrel{\rho}{n}}$ & भें & $\underset{\infty}{\infty}$ & $\begin{array}{l}a \\
\infty \\
\infty\end{array}$ \\
\hline 吾 & $\overrightarrow{6}$ & กู & 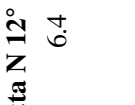 & $\hat{\sigma}$ & $\stackrel{n}{n}$ & $\vec{r}$ & $\stackrel{\circ}{r}$ & $\stackrel{N}{r}$ \\
\hline 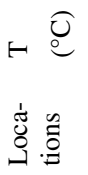 & 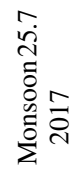 & 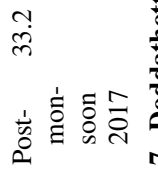 & 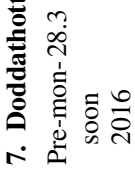 & 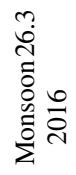 & 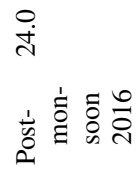 & 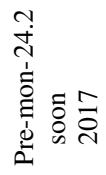 & 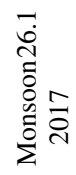 & 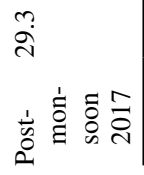 \\
\hline
\end{tabular}




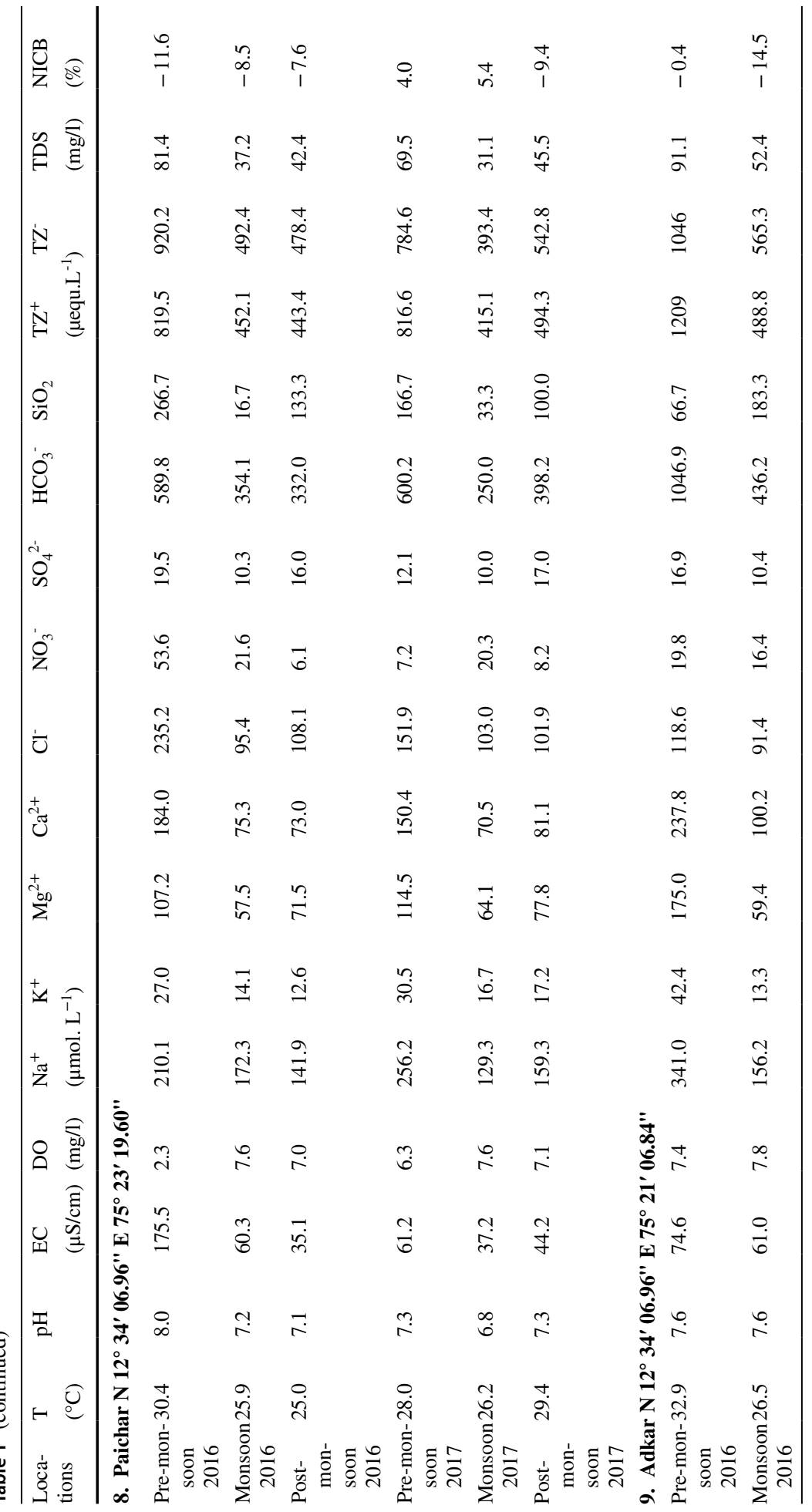




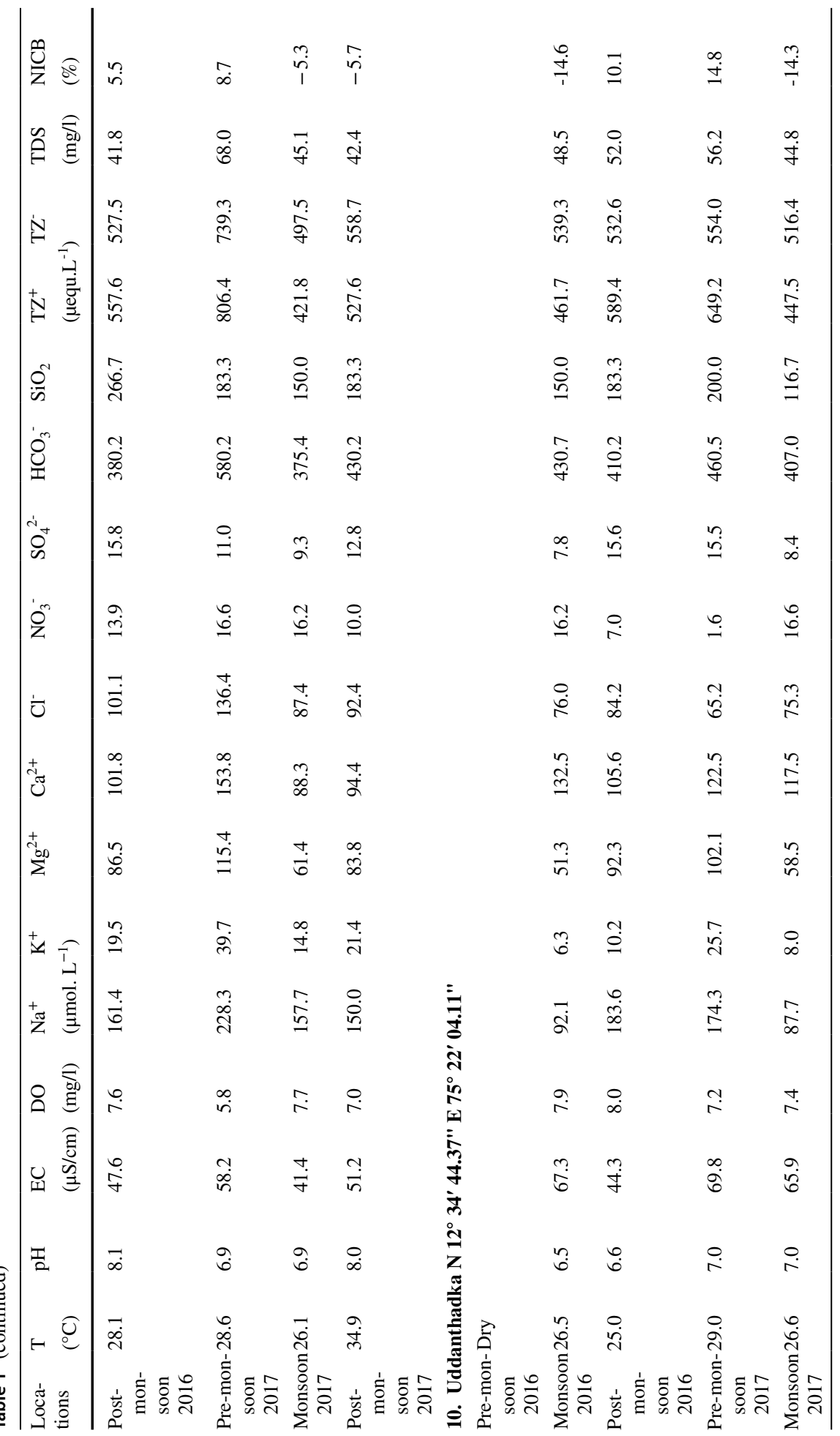




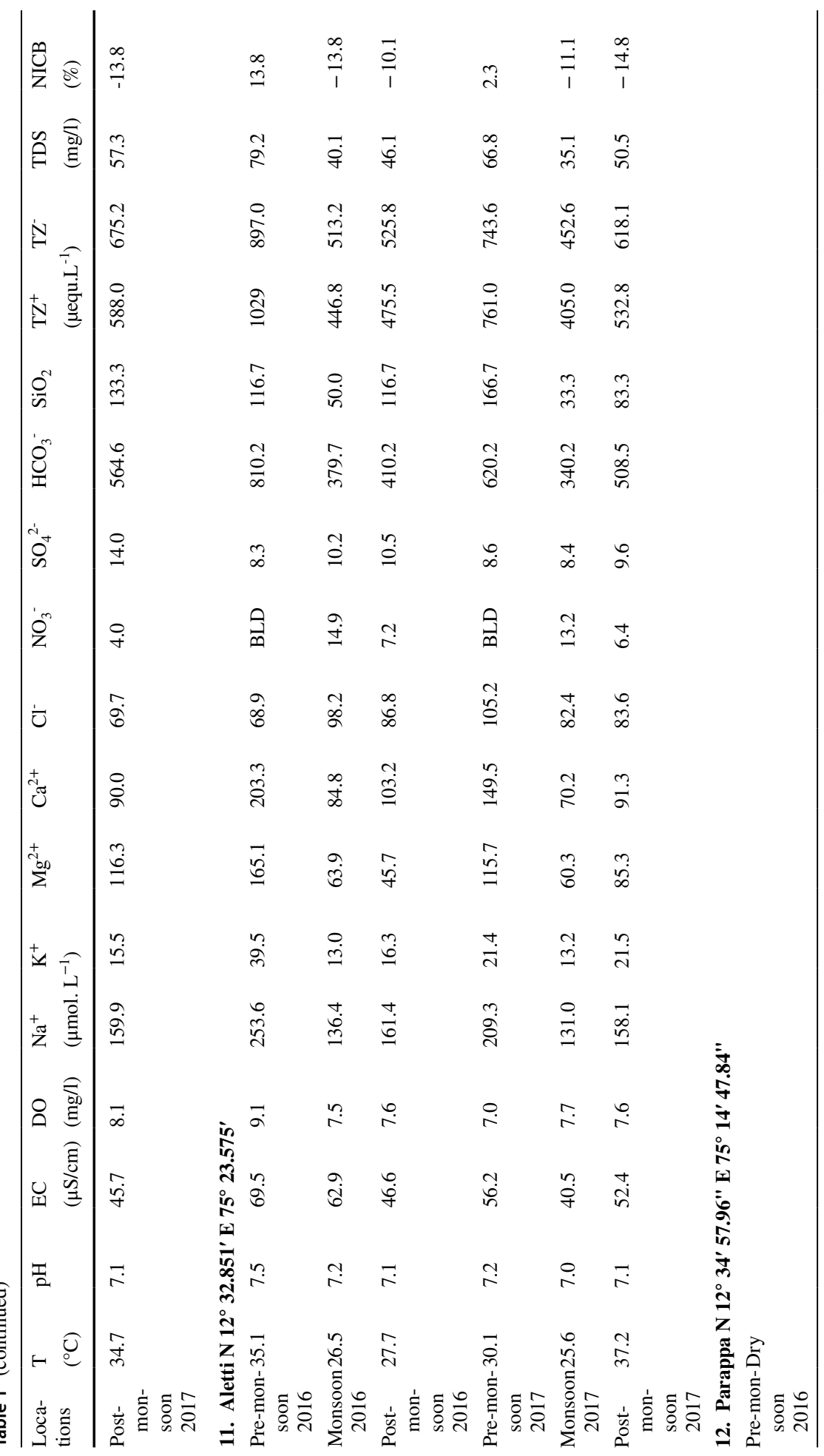




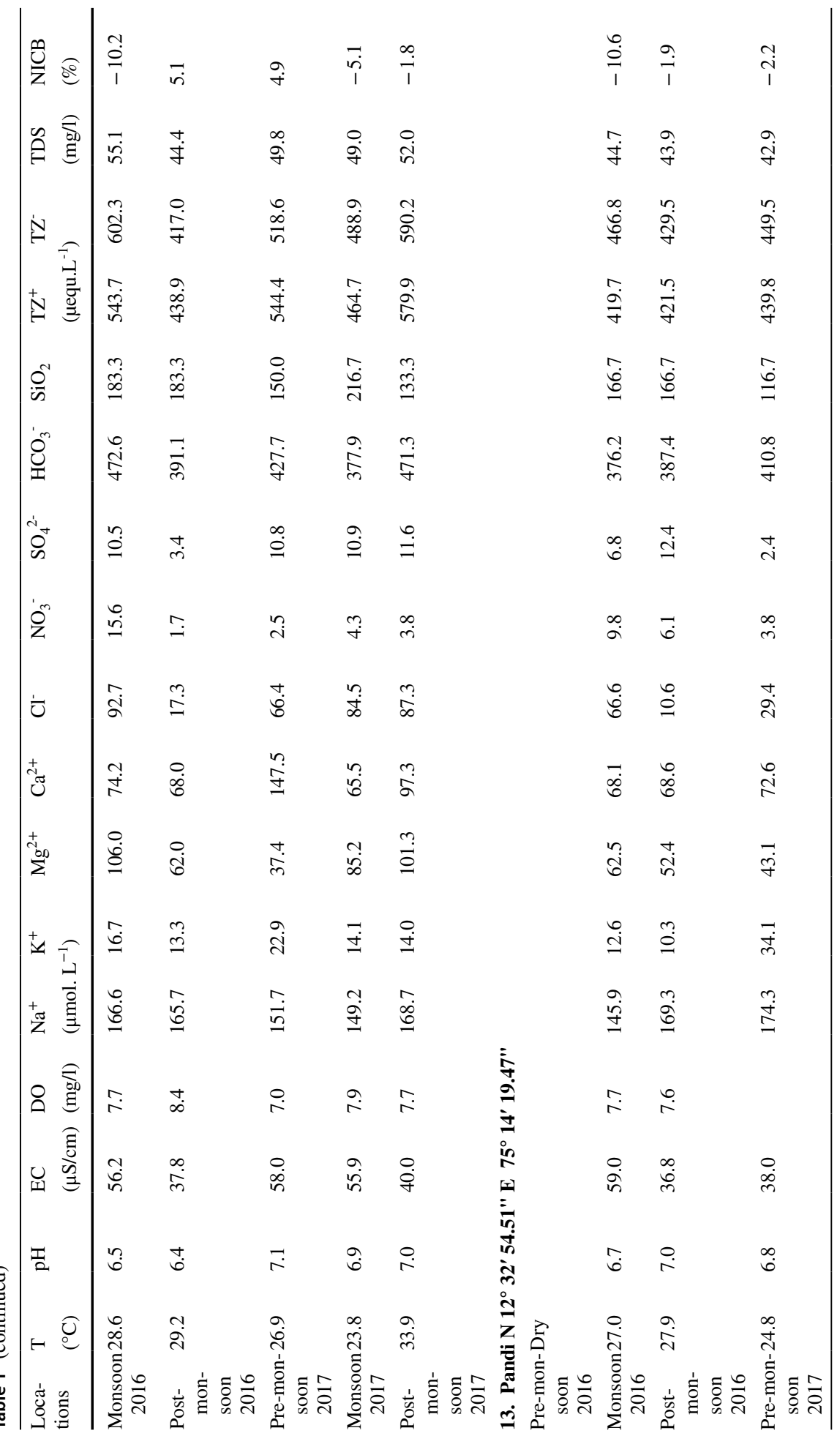




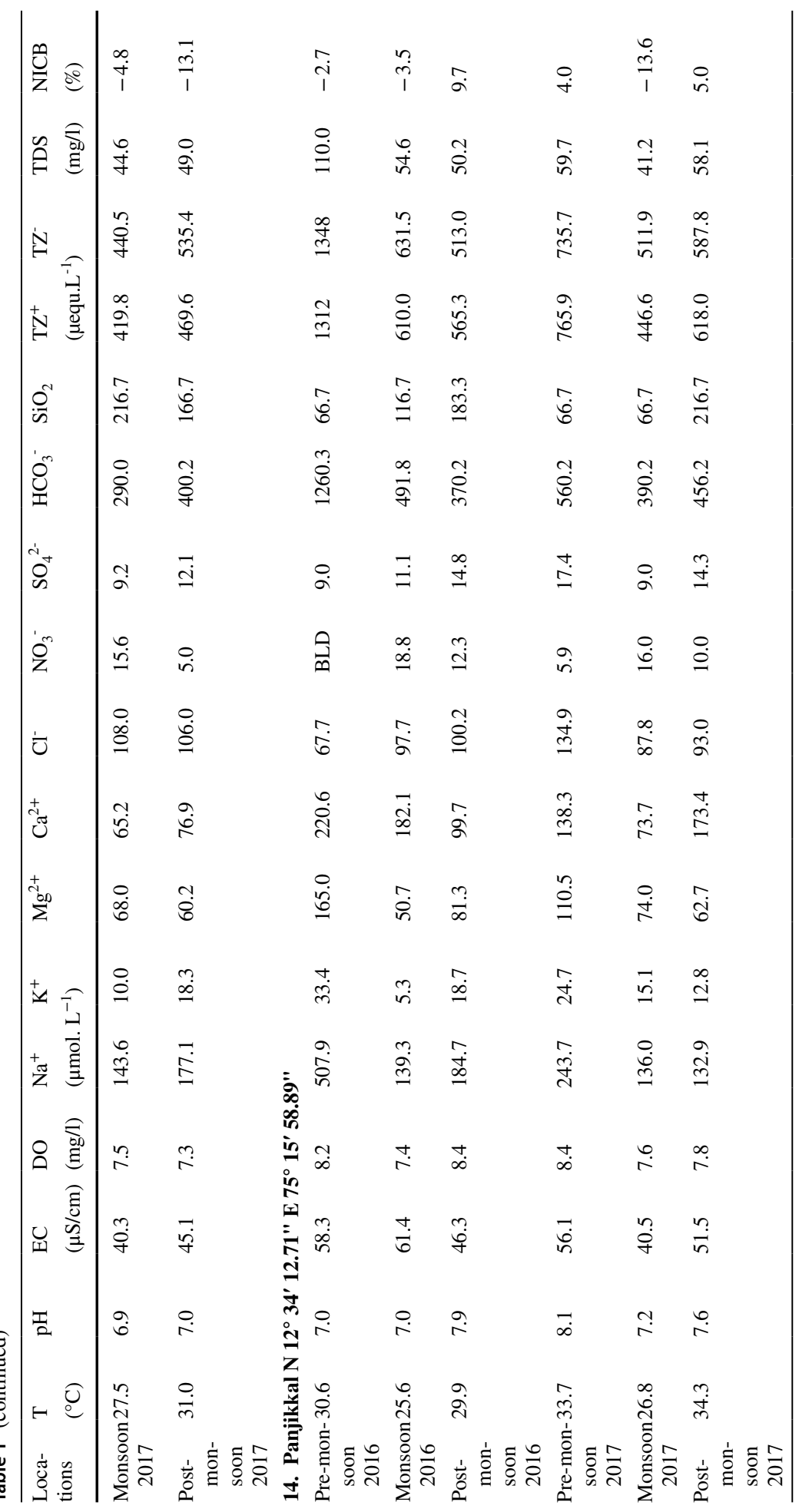




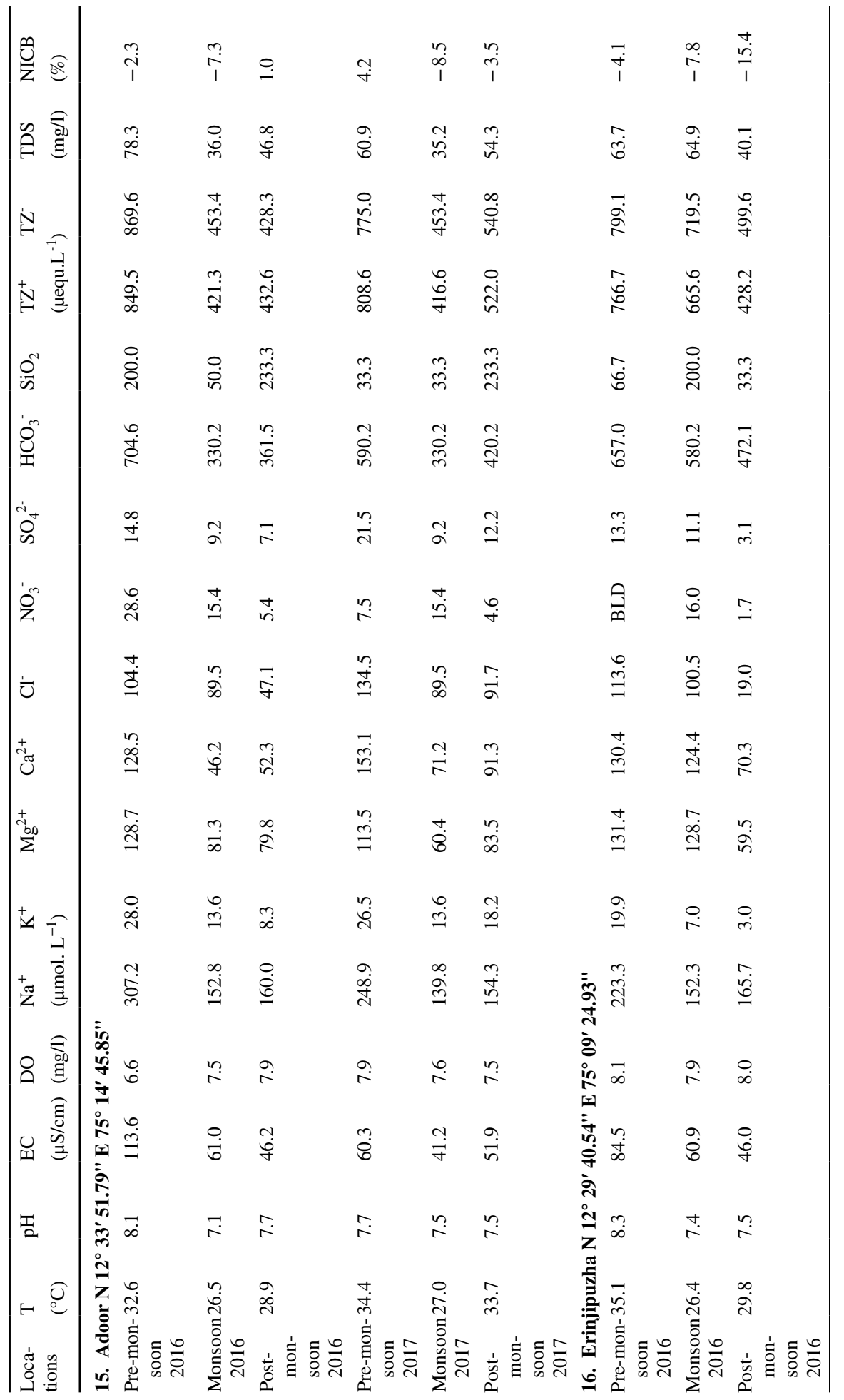




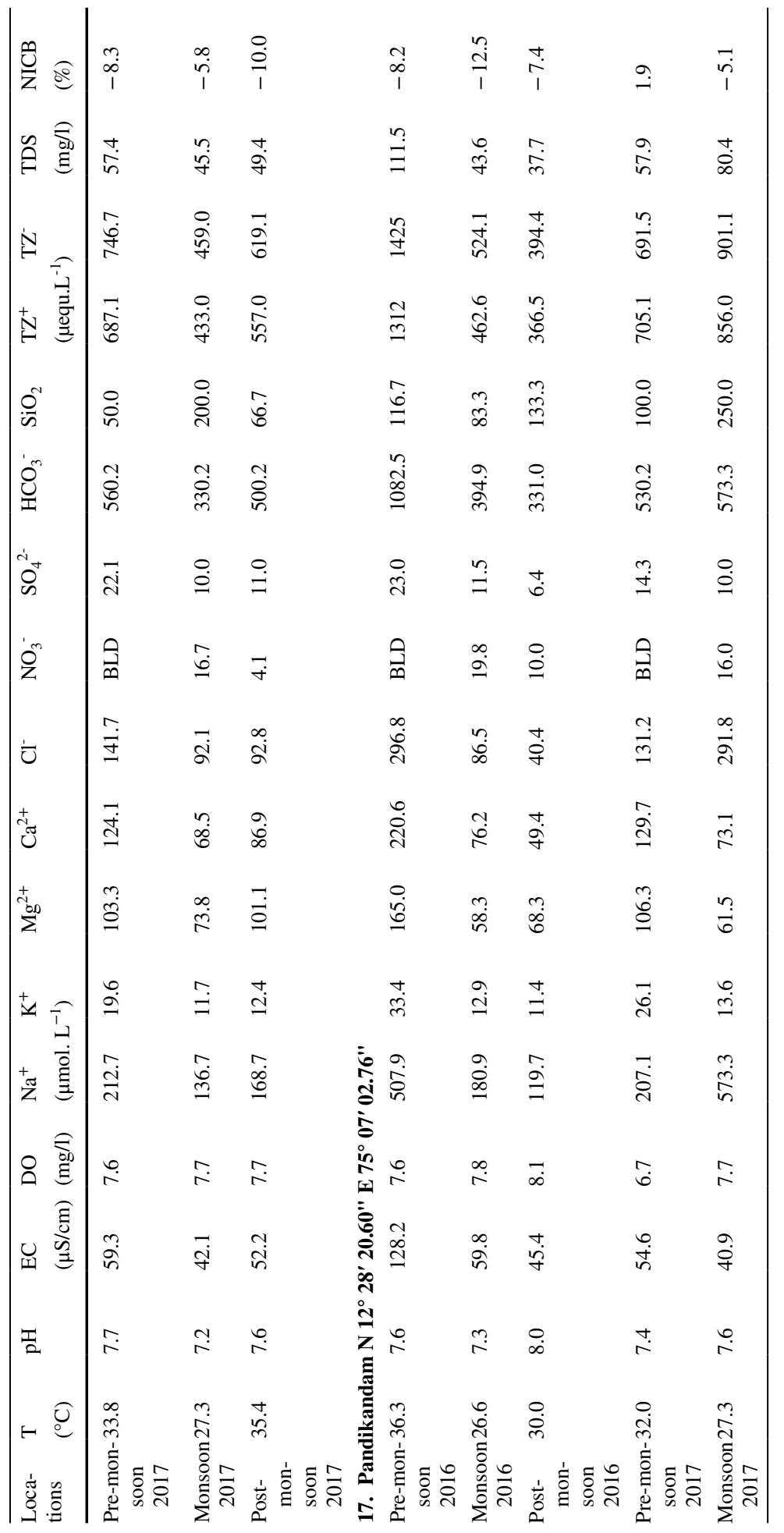




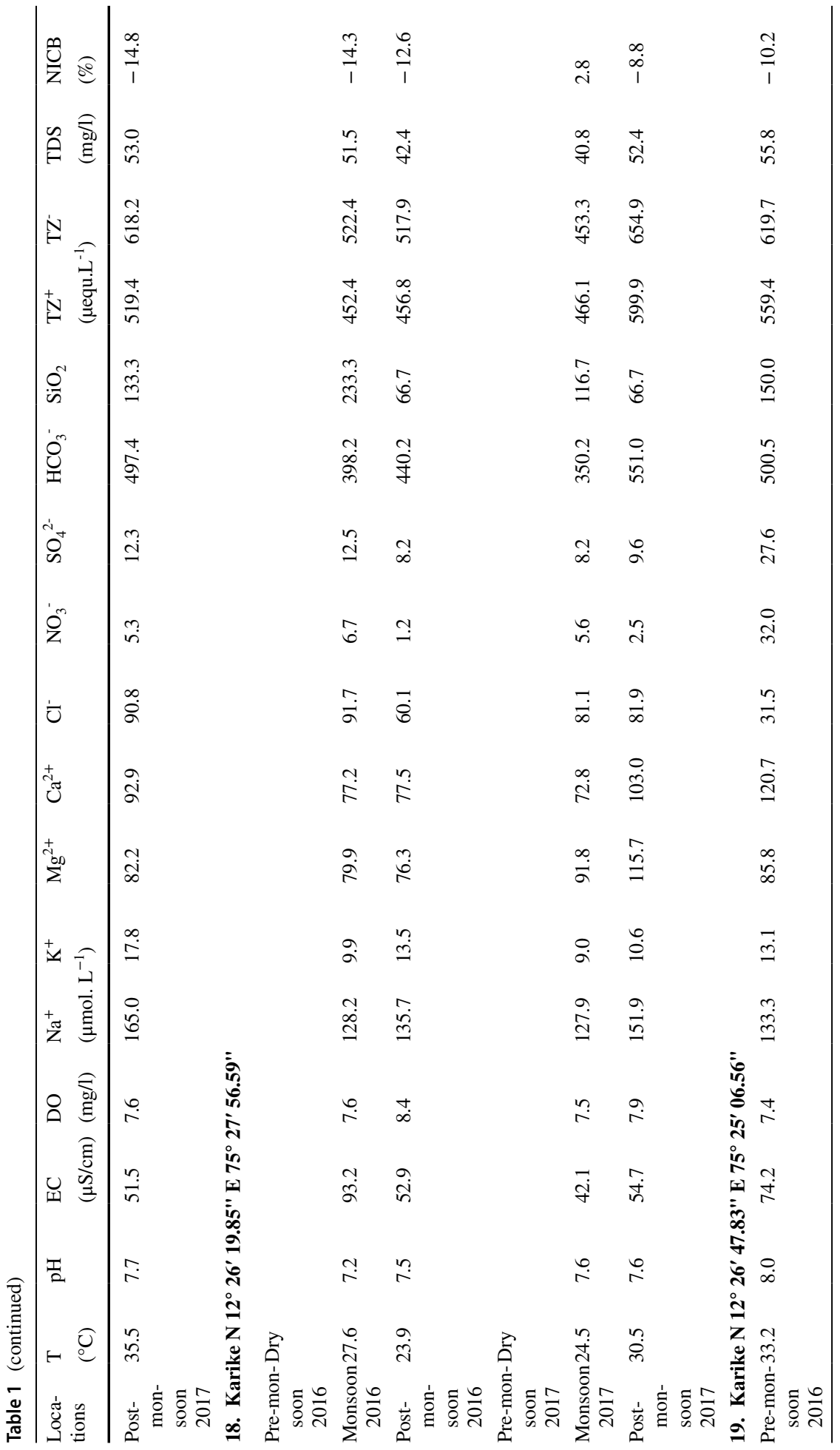




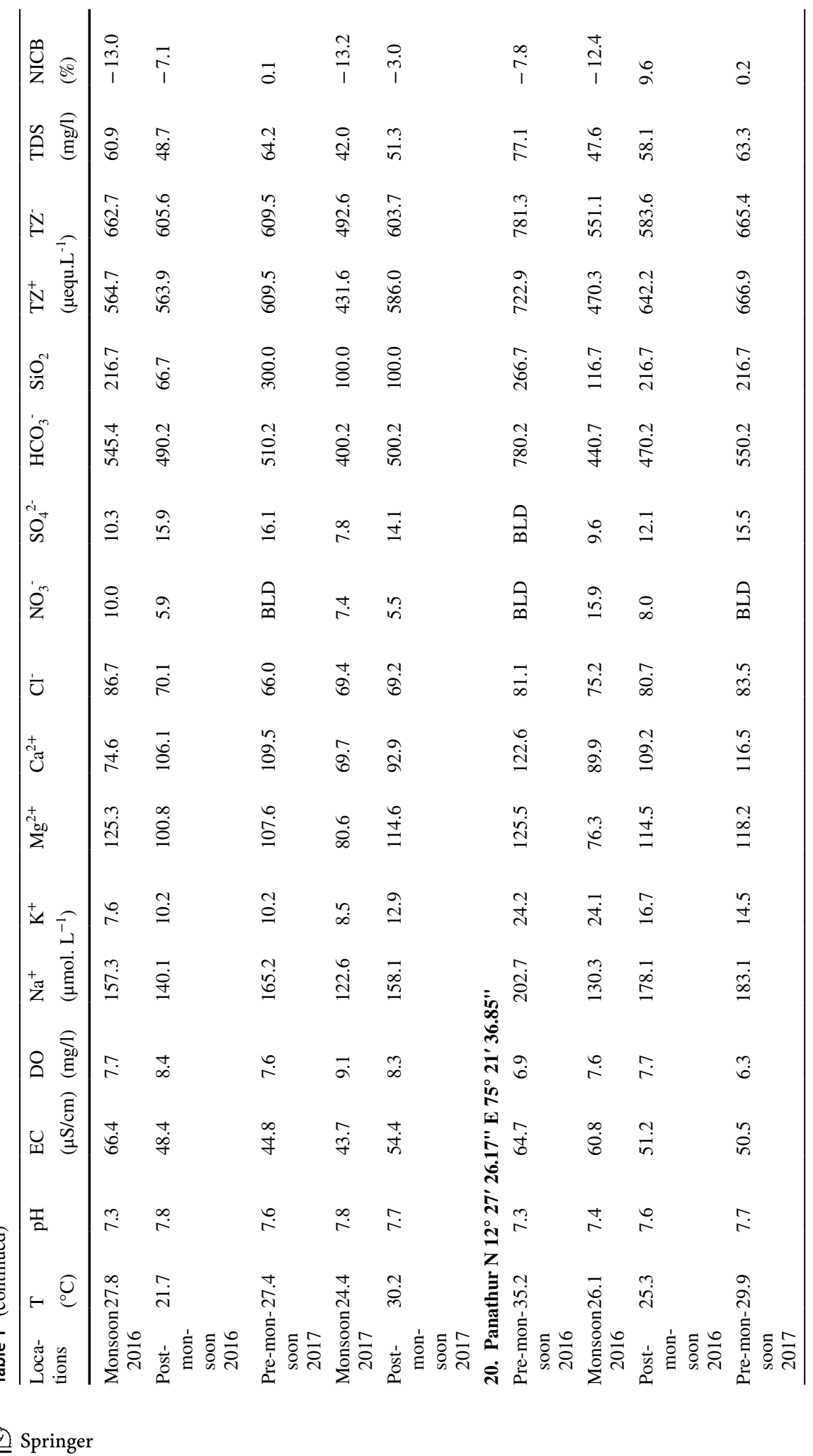




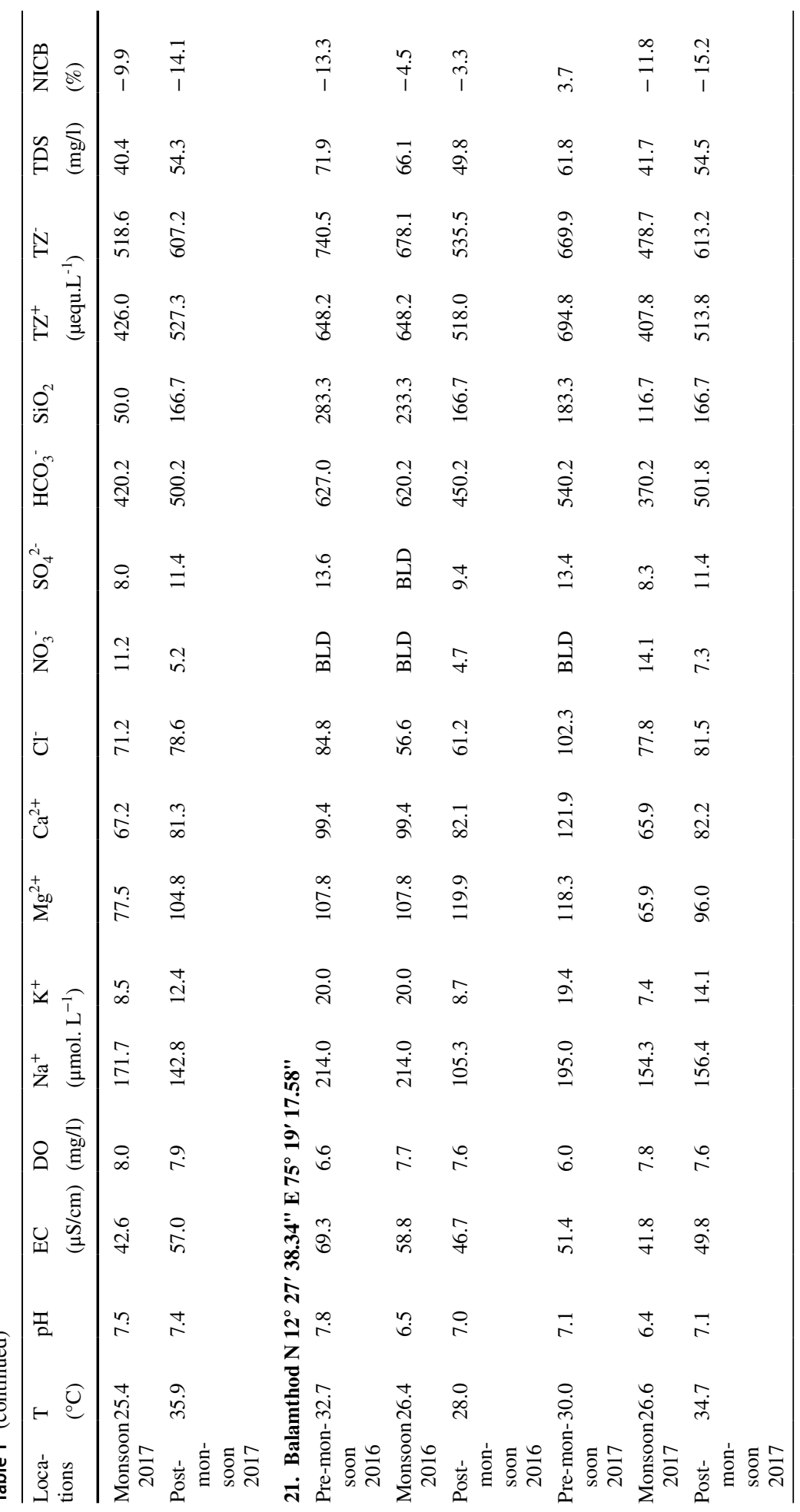




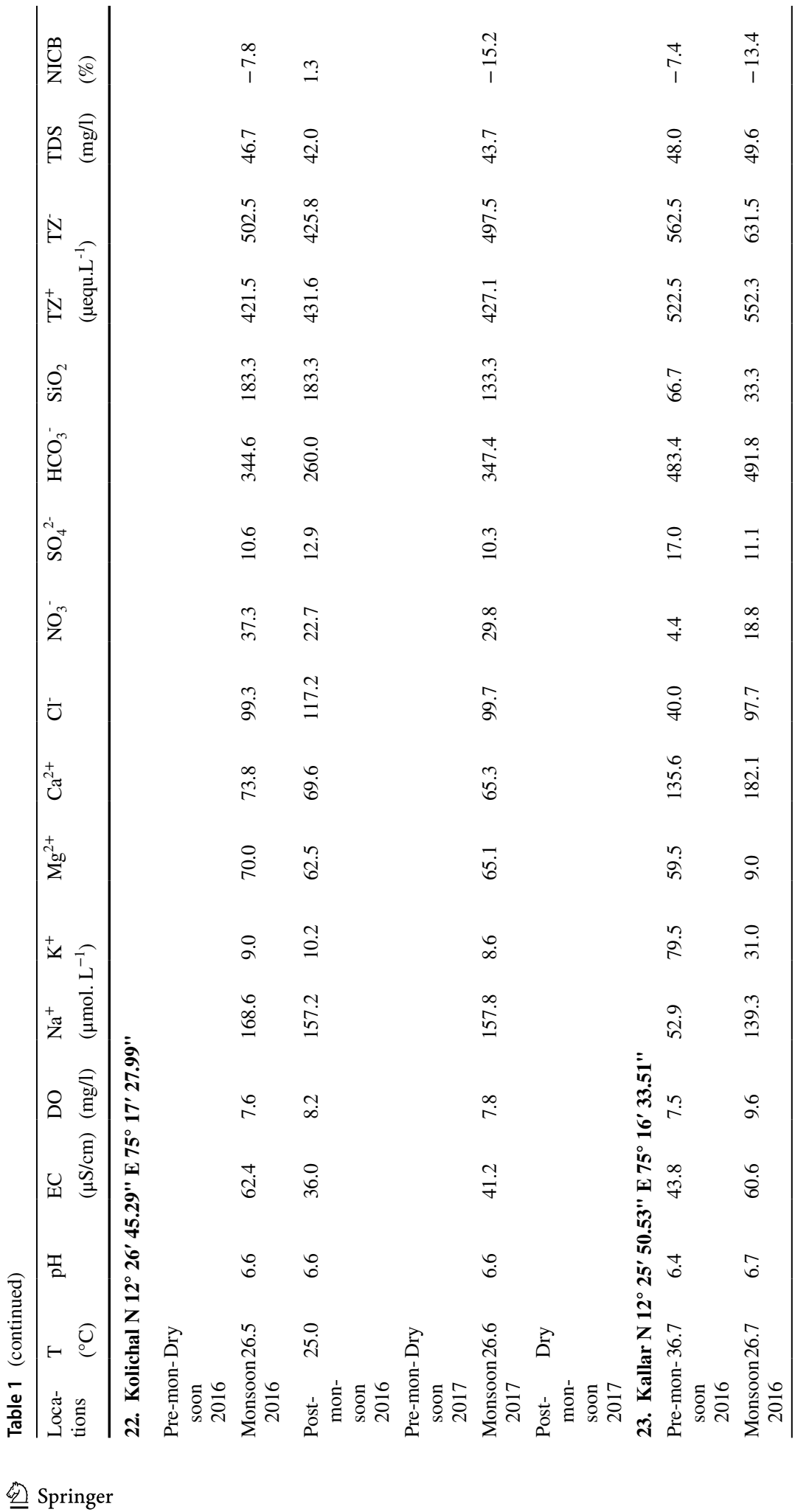




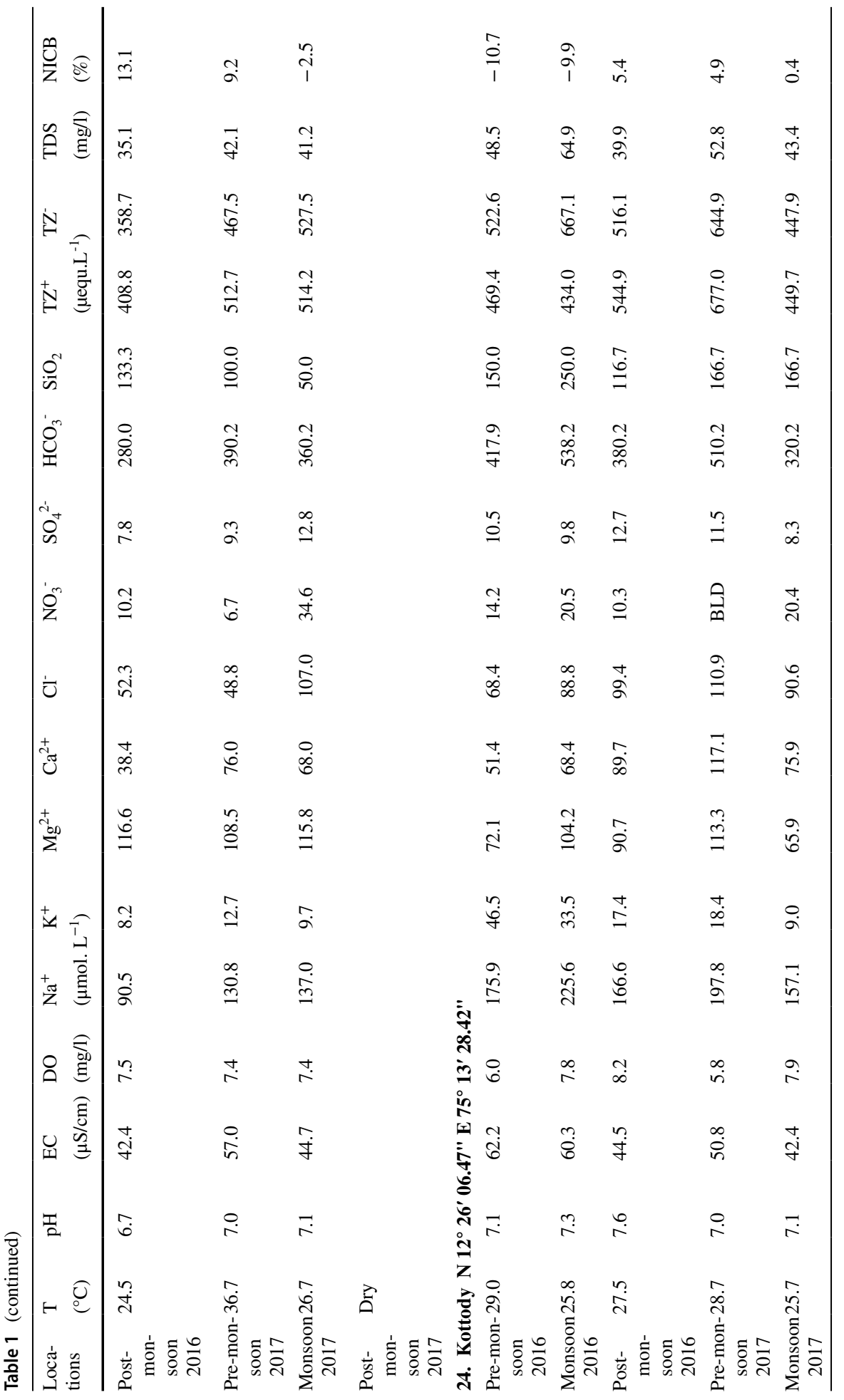




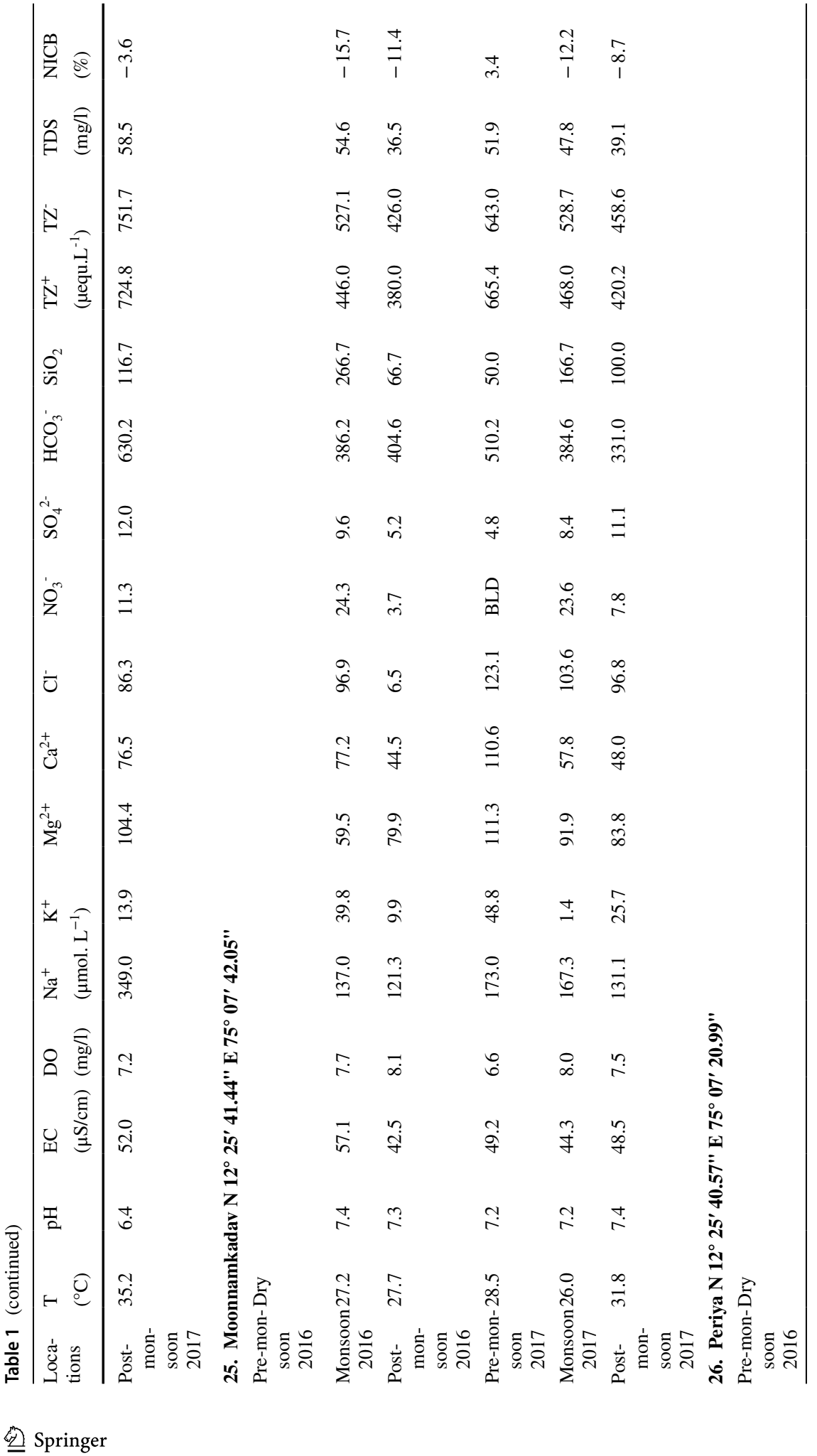




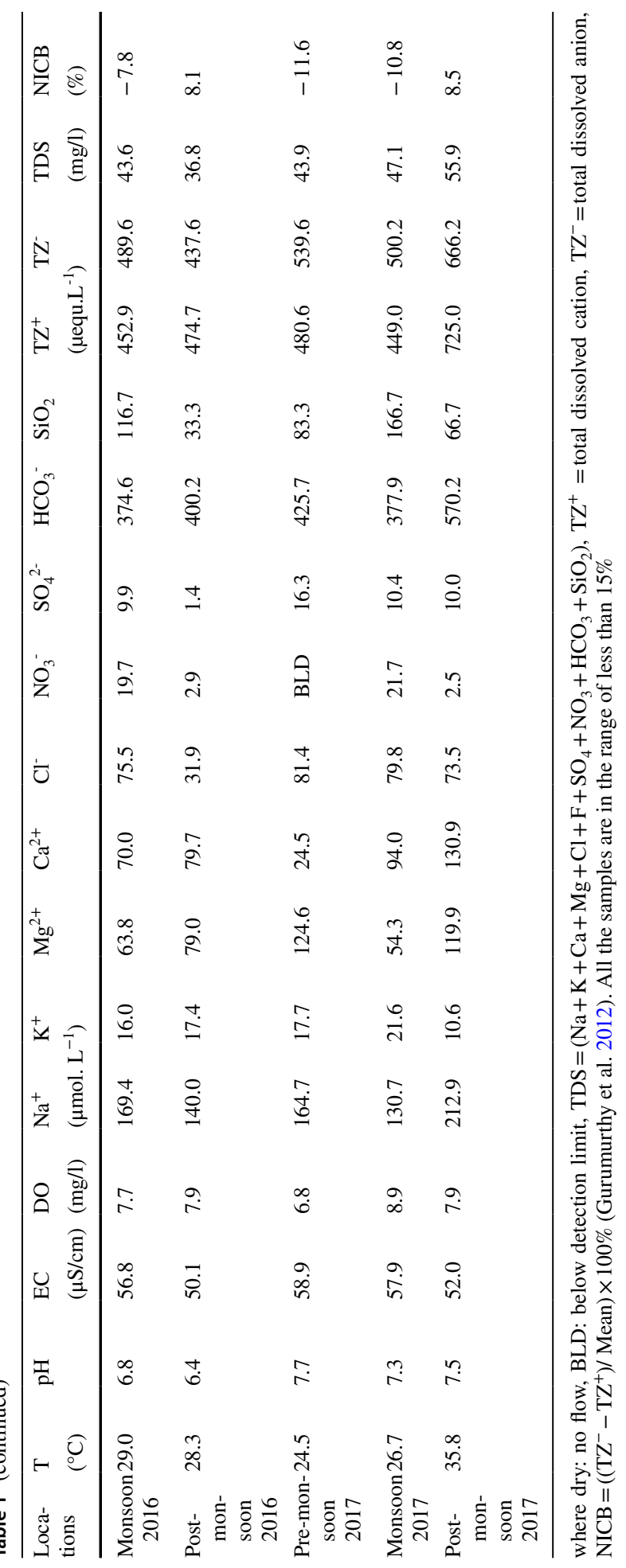


1999) and adjacent river Nethravati (Gurumurthy et al. 2012) but higher than Amazon river (44 mg/l) (Stallard and Edmond, 1983). The TDS (and EC) increases toward the outlet spatially, because of the increasing sea-salt influence.

The mean concentration of major ions in the study area was plotted in bar diagram (Fig. 3). The abundance of the major cations in the samples varied in the order of $\mathrm{Na}^{+}>\mathrm{Ca}^{2+}>\mathrm{Mg}^{2+}>\mathrm{K}^{+}$in all the seasons. $\mathrm{Na}^{+}$is the major cation dominating in the study area. The concentration of $\mathrm{Na}^{+}$was ranging from 1.2 to $13 \mathrm{mg} / \mathrm{l}$ during the study period. The main source of the sodium ion is Na- plagioclase (albite) weathering. The concentration of $\mathrm{K}^{+}$temporally varied from 0.02 to $3.1 \mathrm{mg} / \mathrm{l}$ throughout the study area. The major source is from the $\mathrm{K}^{+}$feldspar of basement rock. $\mathrm{Ca}^{2+}$ was the second dominant ion in the study area. The $\mathrm{Ca}^{2+}$ concentration was ranging from 1 to $10 \mathrm{mg} / \mathrm{l}$ in the study area. The source of calcium is from the basement rock biotite-sillimanite gneiss. Major cation $\mathrm{Mg}^{2+}$ was showing temporal variation from 0.2 to $6.3 \mathrm{mg} / \mathrm{l}$ in their concentration. The main source of magnesium is from the weathering of ferromagnetic minerals.

The average anion concentration in the samples varied in the range $\mathrm{HCO}_{3}{ }^{-}>\mathrm{Cl}^{-}>\mathrm{SO}_{4}{ }^{2-}>\mathrm{NO}_{3}{ }^{-}>\mathrm{F}^{-}$. Bicarbonate concentration ranged from 13 to $77 \mathrm{mg} / 1$ in the river system. Average value of $\mathrm{HCO}_{3}{ }^{-}$of the river Payaswini-Chandragiri is higher than the global average (Gaillardet et al. 1999), Yamuna (Dalai et al. 2002), Kaveri (Pattanaik et al. 2013), Brahmaputra (Galy and France-Lanord, 1999) and river Congo (Dupre et al. 1996). The major source of $\mathrm{HCO}_{3}{ }^{-}$ion is from the weathering of silicate rocks in the catchment. Rainwater reacts with atmospheric $\mathrm{CO}_{2}$ and soil $\mathrm{CO}_{2}$ and leaches the silicate rocks, leading to the release of $\mathrm{HCO}_{3}{ }^{-}$. The major contribution of chloride is from the atmospheric deposition. The concentration was showing high temporal variation, with maximum concentration of $11 \mathrm{mg} / \mathrm{l}$ recorded during the pre-monsoon season. The concentration was ranging from 0.2 to $11 \mathrm{mg} / \mathrm{l}$ in the study area. The higher concentration of chloride in the pre-monsoon season could be because of the low discharge in this season couple with pre-concentration due to evapotranspiration.

The silica concentration in the study area ranged from 2 to $28 \mathrm{mg} / \mathrm{l}$ in pre-monsoon; 1-20 mg/l in monsoon; and 1-16 mg/l during the post-monsoon, respectively. The source of $\mathrm{SiO}_{2}$ in the study area is from the weathering of catchment silicate rocks (Fig. 1).

Minimal concentration of major ions was observed during the monsoon season in the study area, which suggested a high level of dilution due to mixing of rainwater. The
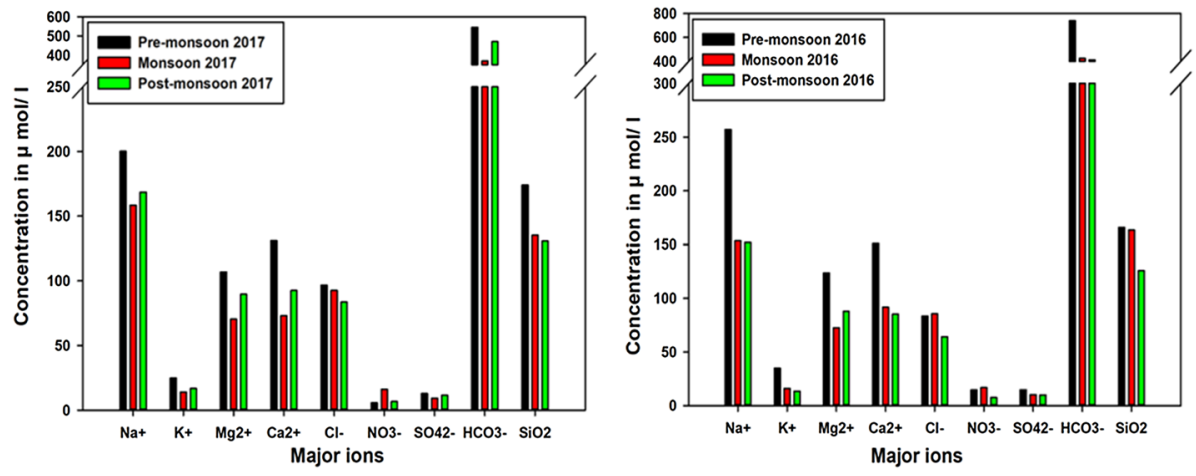

Fig. 3 Bar diagram of major ions concentration $(\mu \mathrm{mol} / \mathrm{l})$ of the Payaswini-Chandragiri river in different seasons 
pre-monsoon sample showed a high level of concentration in all major ions compared to the other two seasons. The yearly mean TDS of this river system $(55 \mathrm{mg} / \mathrm{l})$ is less than half the concentration of the world average rivers (120 mg/l- Gaillardet et al. 1999). During the post-monsoon, major contribution to the river water is from the groundwater discharge. The leaching of terrain rock into the river water through groundwater was the reason for the high ionic concentration in the post-monsoon season in the study area (Thomas et al. 2015). The spatial variable can be noticed in water geochemistry in all the seasons, which is mainly due to the influence of runoff from the different regions.

\subsection{Major ion chemistry in Payaswini-Chandragiri river basin}

The percentage concentration of major ions is plotted in ternary plot (Fig. 4) to evaluate the dominance of ions and percentage concentration of major ions in Payaswini-Chandragiri river water.

On the cation plot (Fig. 4a), most of the samples lie in between the $\mathrm{Na}+\mathrm{K}$ and $\mathrm{Ca}^{2+}$ region. The dominance of $\mathrm{Na}^{+}$and $\mathrm{Ca}^{2+}$ in Payaswini-Chandragiri river water indicates silicate dominant lithology. Forty percentage of the total cations was contributed by $\mathrm{Na}^{+}$, whereas $\mathrm{Ca}^{2+}, \mathrm{Mg}^{2+}$ and $\mathrm{K}^{+}$contributed $35 \%, 19 \%$ and $6 \%$, respectively.

In the anion plot (Fig. 4b), the samples plot in between the $\mathrm{HCO}_{3}{ }^{-}$and $\mathrm{Cl}^{-}$region. $\mathrm{HCO}_{3}{ }^{-}, \mathrm{Cl}^{-}$and $\mathrm{SO}_{4}{ }^{2-}$ contributed $85 \%, 12 \%$ and $3 \%$, respectively. Percentage of anion concentration indicated that the carbonic acid weathering was contributing to high concentration of ions into the river basin, whereas sulfuric acid weathering was negligible.

\subsection{Source of major ions in the Payaswini-Chandragiri river basin}

The dissolved major ion concentration in Payaswini-Chandragiri river water was mainly derived from weathering of basin rocks, atmospheric deposition, anthropogenic activities and biomass deposit (2).

$$
\mathrm{X} \text { river }=\mathrm{X}_{\text {weathering }}+\mathrm{X}_{\mathrm{atmospheric} \mathrm{precipitation}}+\mathrm{X}_{\text {anthropogenic deposition }}+\mathrm{X}_{\text {biomass contribution }}
$$
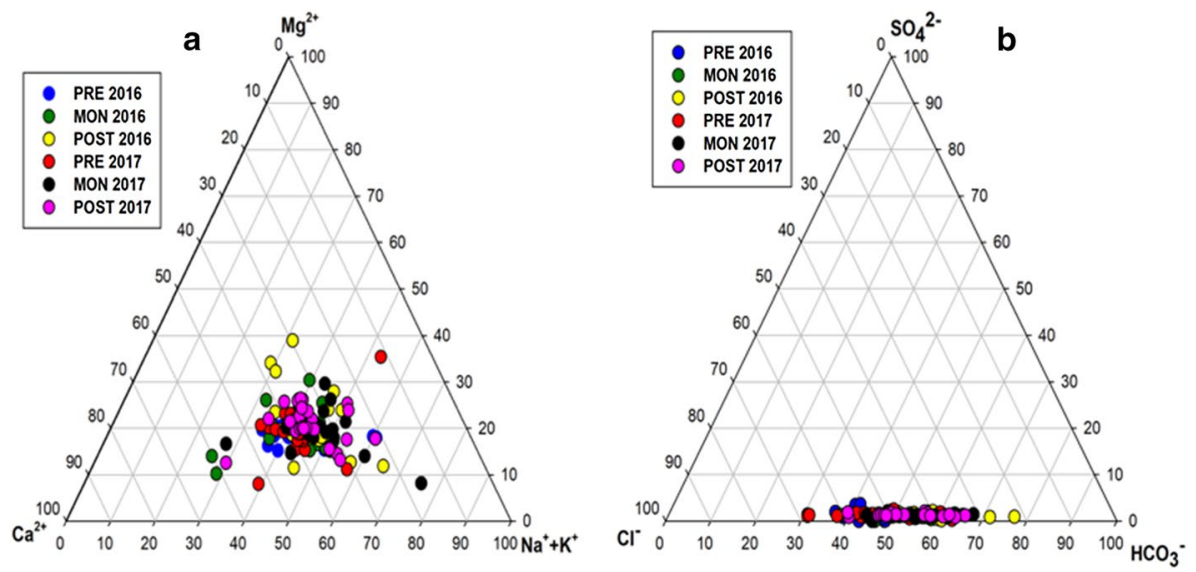

Fig. 4 Ternary plot of a major cations and $\mathbf{b}$ major anions in the river water 
where $X_{\text {weathering }}=X_{\text {carbonate weathering }}+X_{\text {silicate weathering. }}$

According to Krishnaswami and Singh (2005), at steady state, plant uptake and its decay may not change the ionic budget of the river water, thus indicating negligible contribution from the biomass.

\subsubsection{Atmospheric deposition to the river basin}

The scatter plot of $\mathrm{Na} / \mathrm{Cl}$ vs $\mathrm{Cl}$ (Fig. 5) explains the major ion contribution by rainwater to the river water. The cyclic salt input correction (Stallard and Edmond 1981, 1983) deducts atmospheric deposition of $\mathrm{Cl}^{-}$ions from the river water. This is given in Eq:3.

$$
\text { Sea salt corrected ion }=\left(\mathrm{X}_{\text {river }}-\mathrm{Cl}_{\text {river }}\right) *(\mathrm{X} / \mathrm{Cl})_{\text {rain }}
$$

where $\mathrm{X}_{\text {river }}=$ major ion concentration measured in the river water.

The atmospheric contribution from the rain water is corrected using weighted mean value of published rain water data $\left(\mathrm{Cl}^{-}=47 ; \mathrm{Na}^{+}=45 ; \mathrm{Ca}^{2+}=20 ; \mathrm{K}^{+}=5 ; \mathrm{Mg}^{2+}=7\right.$ and $\mathrm{SO}_{4}{ }^{2-}=9 \mu \mathrm{mol} / \mathrm{l}$ ) of Western Ghats (Gurumurthy et al. 2012). In the Payaswini-Chandragiri river system, approximately $50 \%$ of $\mathrm{Na}^{+}$was contributed from the atmosphere to the downstream region (S1) because of its proximity to the Arabian sea. The river water $\mathrm{Na} / \mathrm{Cl}$ molar ratio was higher than 1 , which indicated that $\mathrm{Na}^{+}$was sourced from the catchment bedrock (Hem 1985; Meybeck 1987).

\subsubsection{Major ions from the anthropogenic deposition}

Anthropogenic sources like domestic and industrial sewage and agricultural effluents can modify the ion concentrations of river water (Sun et al. 2010; Han et al. 2010; Liu et al. 2018). $\mathrm{Cl}^{-}, \mathrm{SO}_{4}{ }^{2-}$ and $\mathrm{NO}_{3}{ }^{-}$are the major ions associated with the anthropogenic activity, and they are used as proxies to identify anthropogenic activities in various watersheds (Shin et al. 2011).

The influence of anthropogenic activities on the river in the environment was calculated based on the percentage of pollution as stated by Pacheco and Van der Weijden (1996).

Fig. 5 Scatter plot $\mathrm{Na} / \mathrm{Cl}$ versus $\mathrm{Cl}$ in Payaswini-Chandragiri river basin

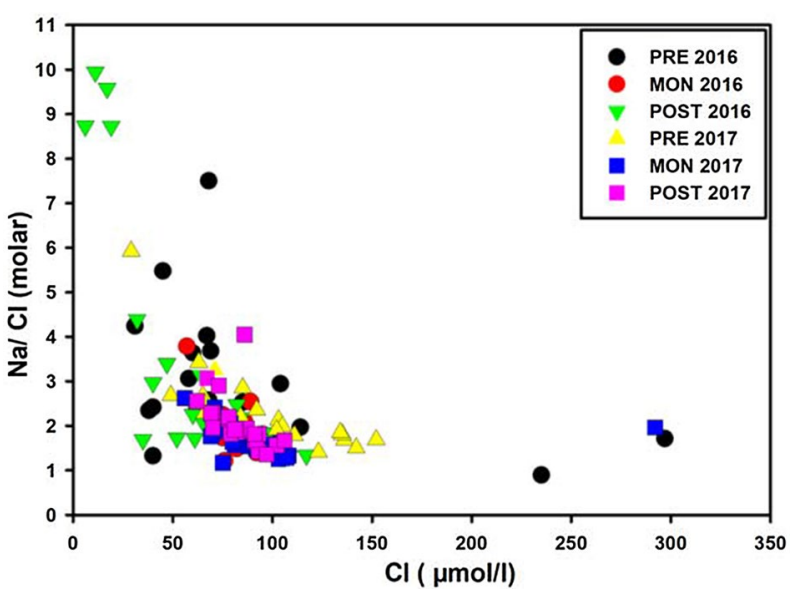


Fig. 6 Variation of pollution percentage versus $\mathrm{Na} / \mathrm{Cl}$ (Faso et al. 2018)

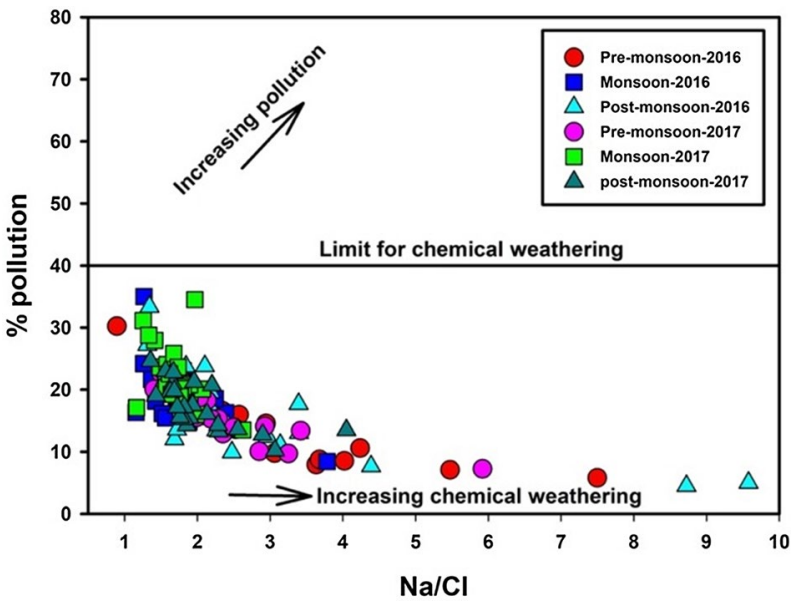

$$
\% \text { pollution }=\left(\mathrm{Cl}+\mathrm{SO}_{4}+\mathrm{NO}_{3}\right) /\left(\mathrm{Cl}+\mathrm{SO}_{4}+\mathrm{NO}_{3}+\mathrm{HCO}_{3}\right) * 100
$$

The percentage of pollution was calculated in every sample and plotted against the $\mathrm{Na} / \mathrm{Cl}$ ratio (Fig. 6). The areas having ratio $\geq 40 \%$ were dominated by pollution from anthropogenic activities, while those with $\leq 40 \%$ were dominated by the rock weathering process. The figure shows all the samples lie within the limits, indicating that the river basin is not affected by anthropogenic activities. So the contribution of major ions, especially chloride, to the Payaswini-Chandragiri river water from the anthropogenic inputs is negligible.

\subsubsection{Major ions from the rock weathering}

Major ion chemistry of Payaswini-Chandragiri river system is dependent on various natural processes. The ionic ratio of $\left(\mathrm{Ca}^{2+}+\mathrm{Mg}^{2+}\right) / \mathrm{HCO}_{3}{ }^{-}$in the river water varied from 0.20 to 0.25 suggesting the significance of chemical weathering of silicate rock in the Payaswini-Chandragiri river hydrochemistry. The ionic ratio of $\mathrm{HCO}_{3}{ }^{-} / \mathrm{Ca}^{2+}$ was higher than 7 in all the seasons, also indicating the dominance of silicate weathering in the study area (Holland 1978). The ratios of $\mathrm{Ca}^{2+}$ and $\mathrm{Mg}^{2+}$ versus $\mathrm{Na}^{+}$were used to calculate the relative concentration from the bedrock (Thomas et al. 2014). The ratios of these indicated that the $\mathrm{Ca}^{2+}$ and $\mathrm{Mg}^{2+}$ were dominated by silicate rock weathering.

The mixing plot of the atmospheric input corrected $\mathrm{Na} / \mathrm{Ca}$ versus $\mathrm{Mg} / \mathrm{Na}$ (Fig. 7) molar ratios suggested that the Payaswini-Chandragiri river water was influenced by the water-silicate rock interaction. The low mean ionic ratios of $\left(\mathrm{Ca}^{2+}+\mathrm{Mg}^{2+}\right) /\left(\mathrm{Na}^{+}+\mathrm{K}^{+}\right)$ and $\mathrm{HCO}_{3}{ }^{-} /\left(\mathrm{Na}^{+}+\mathrm{K}^{+}\right)$also confirmed that the basin was dominated by the silicate rock weathering. The degree of rock-water interaction varied seasonally depending upon the climatic condition (temperature, humidity and rainfall), leading to temporal variation in the concentration of silicate-derived ions. Samples collected in all seasons were plotting in the silicate weathering region. 
Fig. 7 Mixing diagram of normalized $\mathrm{Na}^{+}, \mathrm{Ca}^{2+}$ and $\mathrm{Mg}^{2+}$, the molar ratio (Gaillardet et al. 1999)

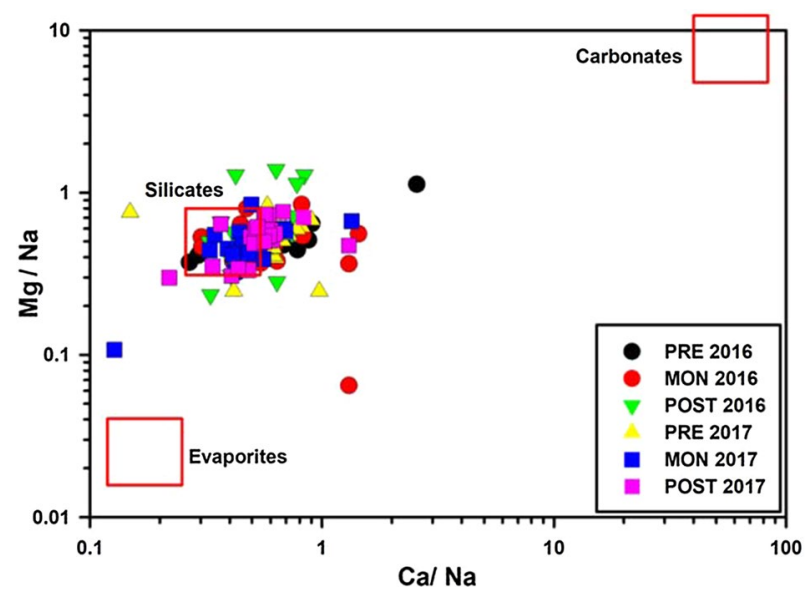

\subsection{Silicate weathering rate and carbon dioxide consumption rate}

\subsubsection{Silicate weathering rate}

Silicate weathering rates of the study area for pre-monsoon, monsoon and post-monsoon in 2016 and 2017 were calculated by using the forward model (Wu et al. 2008), the product of discharge per unit area and concentrations of major elements (Eq. 5).

$$
\mathrm{SWR}=Q\left(\sum(\mathrm{Na}+\mathrm{K}+\mathrm{Mg}+\mathrm{Ca})_{\mathrm{sil}}+\mathrm{SiO}_{2}\right)
$$

where $(\mathrm{Na}+\mathrm{K}+\mathrm{Mg}+\mathrm{Ca})_{\text {sil }}=$ dissolved cations derived from silicate weathering, $Q=$ water discharge per unit area.

During chemical weathering, it is assumed that $\mathrm{Na}^{+}$and $\mathrm{K}^{+}$are derived from the feldspar minerals and $\mathrm{Ca}^{2+}$ and $\mathrm{Mg}^{2+}$ from the pyroxene minerals. After the atmospheric and anthropogenic corrections, remaining cations are from the chemical weathering of major rocks in the river basin. So, silicate-derived $\mathrm{Ca}^{2+}$ and $\mathrm{Mg}^{2+}$ were calculated from the gneissic and charnockite rock, based on the following equations.

$$
\begin{aligned}
& \mathrm{Ca} \text { from silicate rock }=\mathrm{Na} * /(\mathrm{Ca} / \mathrm{Na})_{\text {bedrock }} \\
& \mathrm{Mg} \text { from silicate rock }=\mathrm{Na} * /(\mathrm{Mg} / \mathrm{Na})_{\text {bedrock }}
\end{aligned}
$$

where $\mathrm{Na}^{*}$ is corrected $\mathrm{Na}$ mean concentration from atmospheric inputs. In this study, the basement rock was completely of gneissic and charnockite origin, and thus, the value of $\mathrm{Ca} / \mathrm{Na}$ was 0.41 and $\mathrm{Mg} / \mathrm{Na}$ was 0.325 , respectively. These ratios for the bedrock were obtained through a compilation of previous literature mentioned in Gurumurthy et al. (2012).

The silicate weathering rate of the Payaswini-Chandragiri river system was calculated based on the major ion composition at Adoor and Kottody. Estimated seasonal and annual values are given in Table 2. The average annual silicate weathering rate of Payaswini-Chandragiri river basin was $42 \mathrm{t} \mathrm{km}^{-2} \mathrm{y}^{-1}$ and $36 \mathrm{t} \mathrm{km}^{-2} \mathrm{y}^{-1}$ in 2016 and 2017, respectively. The river system shows higher SWR in monsoon season $\left(37 \mathrm{t} \mathrm{km}^{-2}\right.$ in 2016 and $26 \mathrm{t} \mathrm{km}^{-2}$ in 2017) 
Table 2 Silicate weathering rate and $\mathrm{CO}_{2}$ drawdown rate of the study area in various seasons

\begin{tabular}{llrr}
\hline & Seasons & 2016 & 2017 \\
\hline SWR $\left(\mathrm{t} \mathrm{km}^{-2}\right)$ & Pre-monsoon & 0.63 & 0.39 \\
& Monsoon & 37.30 & 25.97 \\
& Post-monsoon & 8.24 & 9.92 \\
& Annual & 42.17 & 36.28 \\
$\mathrm{CCR}\left(\times 10^{5} \mathrm{~mol} \mathrm{~km}^{-2}\right)$ & Pre-monsoon & 0.13 & 0.10 \\
& Monsoon & 7.97 & 5.83 \\
& Post-monsoon & 1.45 & 2.34 \\
& Annual & 9.55 & 8.28 \\
\hline
\end{tabular}

with $82 \%$ of total discharge. The estimated annual SWR $\left(39 \mathrm{t} \mathrm{km}^{-2} \mathrm{y}^{-1}\right)$ of this study was 0.9 times lower than the adjacent southwest-flowing river Netravathi $\left(42 \mathrm{t} \mathrm{km}^{-2} \mathrm{y}^{-1}\right.$; Gurumurthy et al. 2012), mainly due to the runoff and variations in the drainage area. Comparing this study with the other Indian rivers, the silicate weathering flux of the Payaswini-Chandragiri river was higher than the other Indian rivers. The silicate weathering rates of the Himalayan river systems such as Ganga [10.2-15.2 t km $\mathrm{km}^{-2} \mathrm{y}^{-1}$, (Krishnaswami et al. 1999; Gaillardet et al. 1999; Dalai et al. 2002)], Indus [3.8 t km k $^{-2}$, (Gaillardet et al. 1999)]; Bramhmputra [6.47 $\mathrm{t} \mathrm{km}^{-2} \mathrm{y}^{-1}$, (Das et al. 2016)], Narmada [12.67 $\mathrm{t} \mathrm{km}^{-2} \mathrm{y}^{-1}$; (Gupta et al. 2011)], Tapti (7.32 $\mathrm{t} \mathrm{km}^{-2} \mathrm{y}^{-1}$ ), Kavery [9.44 $\mathrm{t} \mathrm{km}^{-2} \mathrm{y}^{-1}$, (Pattanaik et al. 2013)] are all lower than the Payaswini-Chandragiri river system (Table 3). And the annual SWR of the study area was higher than the river Mahanadi [32 $\mathrm{t} \mathrm{km}^{-2} \mathrm{y}^{-1}$, (Bastia and Equeenuddin 2019)] and Swarnamukhi river [30.57 $\mathrm{t} \mathrm{km}^{-2} \mathrm{y}^{-1}$ (Patel et al. 2020)]. Also, SWR of the study area was higher than the global watersheds like Amazon $\left(13 \mathrm{t} \mathrm{km}^{-2} \mathrm{y}^{-1}\right)$, Mackenzie $\left(1.8 \mathrm{t} \mathrm{km}^{-2} \mathrm{y}^{-1}\right)$, Parana $\left(5 \mathrm{t} \mathrm{km}^{-2}\right.$ $\left.\mathrm{y}^{-1}\right)$, Congo-Zaire $\left(4.2 \mathrm{t} \mathrm{km}^{-2} \mathrm{y}^{-1}\right)$, Orinoco $\left(9.5 \mathrm{t} \mathrm{km}^{-2} \mathrm{y}^{-1}\right)$, Mekong $\left(14.3 \mathrm{t} \mathrm{km}^{-2} \mathrm{y}^{-1}\right)$ and Rio Icacos $\left(40 \mathrm{t} \mathrm{km}^{-2} \mathrm{y}^{-1}\right)$ (Gaillardet et al. 1999).

The southwest-flowing rivers show less SWR as compared to the rivers draining basaltic rock rivers, though are higher than the other Himalayan rivers. The resultant weathering variability could be due to variable lithologies in the Indian river basin and the climatic difference in the tropical region. Higher runoff, temperature and basin formation are the main controlling factors of high SWR in the southwest-flowing rivers. The southwest-flowing rivers show higher SWR comparing to the east-flowing rivers in monsoon season, Krishna Basin and the Western Ghats of the Deccan Traps $\left[53 \mathrm{t} \mathrm{km}^{-2} \mathrm{y}^{-1}\right.$ (Pattanaik et al. 2013; Gurumurthy et al. 2012)], due to intense rainfall and resulting higher runoff (Pattanaik et al. 2013).

The large silicate weathering rate was mostly resulting from the high physical erosion rate (thus exposing the rock surface) in the basin due to high-intensity rainfall (4000 mm/y) (Vinutha 2014). Runoff, granitic terrain, morphology of the study area were the prime factors controlling the silicate weathering rate. Tropical climate speeds up the weathering of silicate minerals and $\mathrm{CO}_{2}$ sequestration in the Western Ghats, while high runoff contributes to excessive bicarbonates into the Arabian Sea (Reddy et al. 2019).

\subsubsection{Carbon dioxide consumption rate (CCR) during silicate rock weathering}

The intense silicate weathering leads to the drawdown of atmospheric $\mathrm{CO}_{2}$. The actual rate of carbon dioxide consumption during silicate rock weathering is calculated using the following equation: 


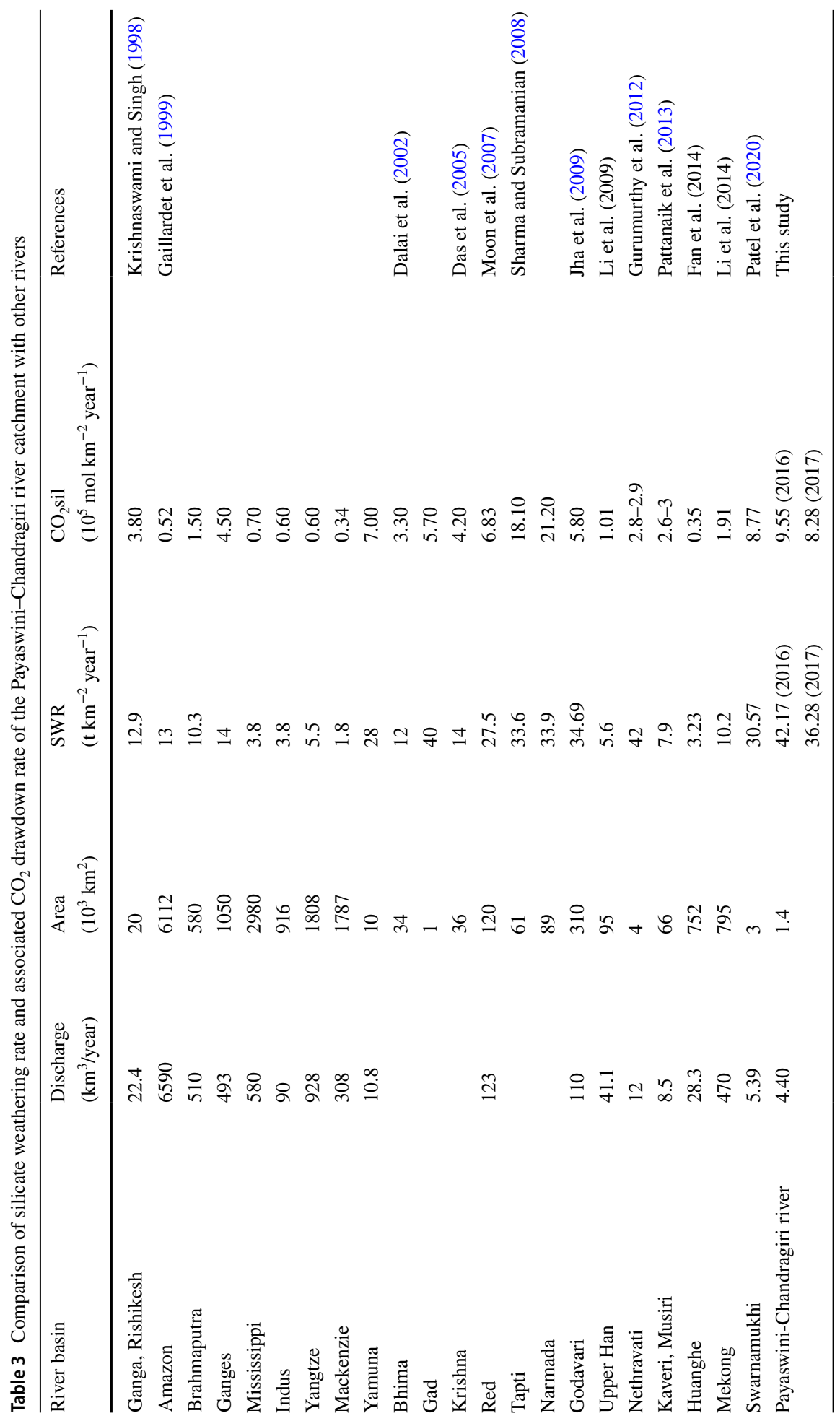



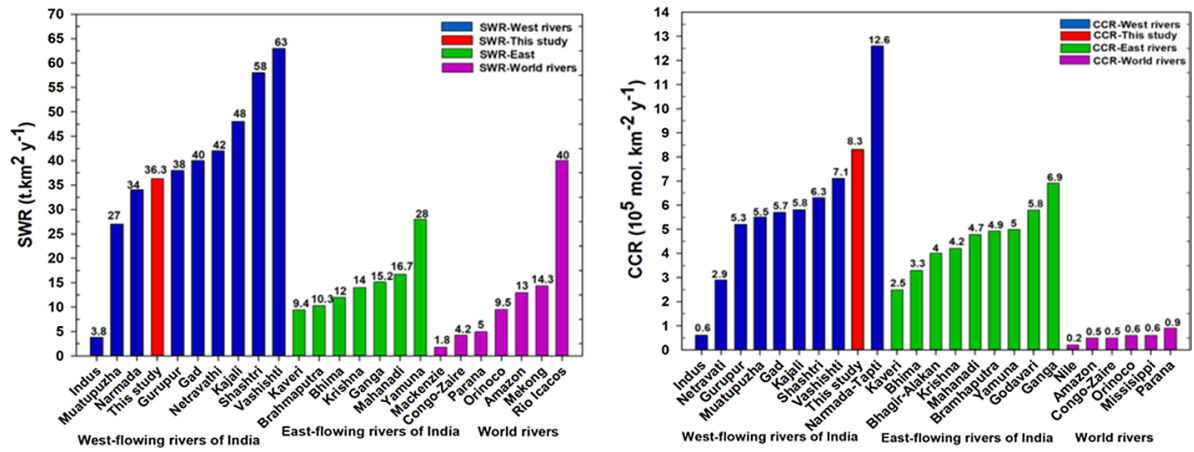

Fig. 8 Comparison of annual silicate weathering rate (SWR) and associated CCR in the Payaswini-Chandragiri river in the year 2017 with major Indian rivers and selected world rivers (Gaillardet et al. 1999; Dalai et al. 2002; Krishnaswami and Singh (1998;Das et al. 2005; Jha et al. 2009; Gupta et al. 2011; Gurumurthy et al. 2012; Pattanaik et al. 2013)

$$
\mathrm{CCR}=Q / A \cdot \sum\left(\mathrm{Na}^{+}+\mathrm{K}^{+}+\mathrm{Mg}^{2+}+\mathrm{Ca}^{2+}\right)_{\text {sil }}
$$

where $Q$ is the discharge in $\mathrm{m}^{3} / \mathrm{s}, A$ is the surface area of the watershed in $\mathrm{km}^{2}$ and $\left(\mathrm{Na}^{+}+\mathrm{K}^{+}+\mathrm{Mg}^{2+}+\mathrm{Ca}^{2+}\right)_{\text {sil }}$ is the silicate-derived cations.

The average annual CCR due to silicate rock weathering of Payaswini-Chandragiri river catchment was found to be $9.6 \times 10^{5} \mathrm{~mol} \mathrm{~km}^{-2} \mathrm{y}^{-1}$ and $8.3 \times 10^{5} \mathrm{~mol} \mathrm{~km}^{-2} \mathrm{y}^{-1}$ for 2016 and 2017, respectively. The Netravathi showed lower CCR $\left(2.9 \times 10^{5} \mathrm{~mol} \mathrm{~km}^{-2} \mathrm{y}^{-1}\right.$, Gurumurthy et al. 2012) than this study.

The CCR of Payaswini-Chandragiri river catchment was higher than other tropical river systems (Fig. 8), Godavari $\left(5.8 \times 10^{5} \mathrm{~mol} \mathrm{~km}^{-2} \mathrm{y}^{-1}\right)$ (Jha et al. 2009) and Yamuna $\left(5.5 \times 10^{5} \mathrm{~mol} \mathrm{~km} \mathrm{k}^{-2} \mathrm{y}^{-1}\right.$ ) (Krishnaswami and Singh 2005), Bhagirathi-Alaknanda $\left(4 \times 10^{5} \mathrm{~mol} \mathrm{~km}^{-2} \mathrm{y}^{-1}\right)$ (Krishnaswami and Singh 1998), Narmada and Tapti Rivers $\left(12.6 \times 10^{5} \mathrm{~mol} \mathrm{~km}^{-2} \mathrm{y}^{-1)}\right.$, Krishna Basin and Western Ghats of the Deccan Traps $\left(7.4 \times 10^{5} \mathrm{~mol} \mathrm{~km}^{-2} \mathrm{y}^{-1)}\right.$ (Dessert et al. 2003) and Brahmaputra $\left(5.2 \times 10^{5} \mathrm{~mol} \mathrm{~km}^{-2} \mathrm{y}^{-1}\right)$ (Das et al. 2016), Mahanadi ( $4.78 \times 10^{5} \mathrm{~mol} \mathrm{~km}^{-2} \mathrm{y}^{-1)}$ (Bastia and Equeenuddin 2019) and Kaveri basin $\left(3.83 \times 10^{5} \mathrm{~mol} \mathrm{~km}^{-2} \mathrm{y}^{-1)}\right.$ (Pattanaik et al. 2013).

The calculated CCR during silicate weathering in the study area was, however, higher than the world river watersheds (Table 3) such as Amazon $\left(0.5 \times 10^{5} \mathrm{~mol} \mathrm{~km}^{-2}\right.$ $\left.\mathrm{y}^{-1}\right)$, Congo-Zaire $\left(0.5 \times 10^{5} \mathrm{~mol} \mathrm{~km}^{-2} \mathrm{y}^{-1}\right)$, Orinoco $\left(0.6 \times 10^{5} \mathrm{~mol} \mathrm{~km}^{-2} \mathrm{y}^{-1}\right)$, Parana $\left(0.9 \times 10^{5} \mathrm{~mol} \mathrm{~km}^{-2} \mathrm{y}^{-1}\right)$ (Gaillardet et al. 1999) and Indus basin $\left(0.6 \times 10^{5} \mathrm{~mol} \mathrm{~km}^{-2} \mathrm{y}^{-1}\right)$ (Fig. 8). Intense monsoonal rainfall and the dominant silicate minerals in the catchment area could be the reasons for the higher consumption of $\mathrm{CO}_{2}$ during the silicate weathering of Payaswini-Chandragiri river in the monsoonal season $\left(8 \times 10^{5} \mathrm{~mol} \mathrm{~km}^{-2}\right.$ and $6 \times 10^{5} \mathrm{~mol} \mathrm{~km}^{-2}$ in 2016 and 2017) compared to other seasons (Table 2).

\section{Conclusions}

This study analyzed the geochemical characteristics and tabulated the atmospheric $\mathrm{CO}_{2}$ drawdown rate during silicate weathering of a tropical river catchment, Payaswini-Chandragiri river basin, southwestern coast of India. The analyzed results indicate that the 
hydrochemical characteristics of river water gradually change with seasons compared to spatial variations due to runoff, climate and temperature. The dominance of major ions in the Payaswini-Chandragiri river system follows the order of $\mathrm{HCO}_{3}{ }^{-}>\mathrm{Cl}^{-}>\mathrm{SO}_{4}{ }^{2-}>\mathrm{NO}_{3}{ }^{-}$ for anions, whereas major cation concentration followed the order $\mathrm{Na}^{+}>\mathrm{Ca}^{2+}>\mathrm{Mg}^{2+}>\mathrm{K}^{+}$ in all the seasons. The $\mathrm{Na}^{+}$normalized $\mathrm{Ca}^{2+}$ versus $\mathrm{Mg}^{2+}$ and $\mathrm{HCO}_{3}{ }^{-}$plots suggested the contribution of major ions through silicate minerals.

The estimated silicate weathering rate in Payaswini-Chandragiri river catchment was $42 \mathrm{t} \mathrm{km}^{-2} \mathrm{y}^{-1}$ in the year 2016 and $36 \mathrm{t} \mathrm{km}^{-2} \mathrm{y}^{-1}$ in 2017. This value was 0.9 times that of the adjacent west-flowing river Nethravati (Gurumurthy et al. 2012). The average annual CCR due to silicate rock weathering of Payaswini-Chandragiri river catchment was $9.6 \times 10^{5} \mathrm{~mol} \mathrm{~km}^{-2} \mathrm{y}^{-1}$ and $8.3 \times 10^{5} \mathrm{~mol} \mathrm{~km}^{-2} \mathrm{y}^{-1}$ for 2016 and 2017, respectively.

Supplementary Information The online version contains supplementary material available at https://doi. org/10.1007/s10498-021-09394-2.

Acknowledgements The first author is thankful to DST-INSPIRE fellowship (IF150682) provided by the Department of Science and Technology. Central Instrumentation Facility (CIF), MIT, is thanked for providing the analytical facilities. The insightful and painstaking reviews from the referees are greatly appreciated.

Funding Open access funding provided by Manipal Academy of Higher Education, Manipal.

Open Access This article is licensed under a Creative Commons Attribution 4.0 International License, which permits use, sharing, adaptation, distribution and reproduction in any medium or format, as long as you give appropriate credit to the original author(s) and the source, provide a link to the Creative Commons licence, and indicate if changes were made. The images or other third party material in this article are included in the article's Creative Commons licence, unless indicated otherwise in a credit line to the material. If material is not included in the article's Creative Commons licence and your intended use is not permitted by statutory regulation or exceeds the permitted use, you will need to obtain permission directly from the copyright holder. To view a copy of this licence, visit http://creativecommons.org/licenses/by/4.0/.

\section{References}

Ahmad T, Khanna PP, Chakrapani GJ, Balakrishnan S (1998) Geochemical characteristics of water \& sediment of the Indus River, Trans-Himalaya, India: constraints on weathering \& erosion. J Asian Earth Sci 16(2-3):333-346. https://doi.org/10.1016/S0743-9547(98)00016-6

Andersson L, Wilk J, Todd MC, Hughes DA, Earle A, Kniveton D, Savenije HHG (2006) Impact of climate change and development scenarios on flow patterns in the Okavango River. J Hydrol 331(1-2):43-57. https://doi.org/10.1016/j.jhydrol.2006.04.039

Bastia F, Equeenuddin SM (2019) Chemical weathering and associated $\mathrm{CO}_{2}$ consumption in the Mahanadi River Basin, India. J Asian Earth Sci 174:218-231. https://doi.org/10.1016/j.jseaes.2018.12.010

Berner RA (1991) A model for atmospheric $\mathrm{CO}_{2}$ over Phanerozoic time. Am J Sci 291:339-376. https://doi. org/10.2475/ajs.291.4.339

Dalai TK, Krishnaswami S, Sarin MM (2002) Major ion chemistry in the headwaters of the Yamuna river system: chemical weathering, its temperature dependence and $\mathrm{CO}_{2}$ consumption in the Himalaya. Geochem Cosmochim Acta 66:3397-3416. https://doi.org/10.1016/S0016-7037(02)00937-7

Das A, Krishnaswami S, Sarin MM, Pande K (2005) Chemical weathering in the Krishna basin and western Ghats of the Deccan traps, India: rates of basalt weathering and their controls. Geochem Cosmochim Acta 69:2067-2084. https://doi.org/10.1016/j.gca.2004.10.014

Das P, Sarma KP, Jha PK, Ranjan R, Herbert R, Kumar M (2016) Understanding the cyclicity of chemical weathering and associated $\mathrm{CO}_{2}$ consumption in the Brahmaputra River Basin (India): the role of major rivers in climate change mitigation perspective. Aquat Geochem 22(3):225-251. https://doi.org/ 10.1007/s10498-016-9290-6

Dekov VM, Komy Z, Araújo F, Van Put A, Van Grieken R (1997) Chemical composition of sediments, suspended matter, river water and ground water of the Nile (Aswan-Sohag traverse). Sci Total Environ 201(3):195-210 
Dessert CD, Gaillardet B, François J, Louis M, Allègre CJ (2003) Basalt weathering laws and the impact of basalt weathering on the global carbon cycle. Chem Geol 202(3-4):257-273. https://doi.org/10.1016/j. chemgeo.2002.10.001

Dupre B, Gaillardet J, Rousseau D, Allegre CJ (1996) Major and trace elements of river borne material: the Congo Basin. Geochem Cosmochim Acta 60:1301-1321. https://doi.org/10.1016/0016-7037(96) 00043-9

Faso BS, Sawadogo A, Yoni S, Nimi M, Zongo M, Bamba O, Ousmane B (2018) Hydrogeochemical characterization of dug well water and its suitability for domestic water supply in the village of Passakongo, Dédougou Municipality, hydrogeochemical characterization of dug well water \& its suitability for domestic water supply in T. Environ Nat Resour Res 8(3):126-137. https://doi.org/10.5539/enrr. v8n3p126

Gaillardet J, Dupre B, Louvat P, Allegre CJ (1999) Global silicate weathering and $\mathrm{CO}_{2}$ consumption rates deduced from the chemistry of large rivers. Chem Geol 159:3-30. https://doi.org/10.1016/S00092541(99)00031-5

Galy A, France-Lanord C (1999) Weathering processes in the Ganges-Brahmaputra basin and the riverine alkalinity budget. Chem Geol 159:31-60. https://doi.org/10.1016/S0009-2541(99)00033-9

Guo H, Wang Y (2005) Geochemical characteristics of shallow groundwater in Datong Basin, Northwestern China. J Geochem Explor 87(3):109-120. https://doi.org/10.1016/j.gexplo.2005.08.002

Gupta H, Chakrapani GJ, Selvaraj K, Kao SJ (2011) The fluvial geochemistry, contributions of silicate, carbonate and saline-alkaline components to chemical weathering flux and controlling parameters: Narmada River (Deccan Traps), India. Geochim Cosmochim Acta 75(3):800-824. https://doi.org/ 10.1016/j.gca.2010.11.010

Gurumurthy GP, Balakrishna KR, Braun J, Audry JJ, Shankar S, Udaya HN, Manjunatha BR (2012) Controls on intense silicate weathering in a Tropical River, Southwestern India. Chem Geol 300301:61-69. https://doi.org/10.1016/j.chemgeo.2012.01.016

Han G, Tang Y, Zhifang Xu (2010) Fluvial geochemistry of rivers draining Karst Terrain in Southwest China. J Asian Earth Sci 38(1-2):65-75. https://doi.org/10.1016/j.jseaes.2009.12.016

Hem JD (1985) Study and interpretation of the chemical characteristics of natural water, vol 2254. Department of the Interior, US Geological Survey.

Huang X, Sillanpää M, Gjessing ET, Vogt RD (2009) Water quality in the Tibetan Plateau: major ions and trace elements in the headwaters of four major Asian rivers. Sci Total Environ 407(24):62426254. https://doi.org/10.1016/j.scitotenv.2009.09.001

Huh Y (2003) Chemical weathering and climate - a global experiment: a review. Geosci J 7(3):277-288. https://doi.org/10.1007/BF02910294

Jha PK et al (2009) Chemical weathering and associated $\mathrm{CO}_{2}$ consumption in the Godavari River Basin, India. Chem Geol 264(1-4):364-374. https://doi.org/10.1016/j.chemgeo.2009.03.025

Jiang LY, Wang Z, Liu R, Wang Z, Lei Wu, Shanshan. (2015) Hydrochemistry of the middle and upper reaches of the Yarlung Tsangpo River system: weathering processes and $\mathrm{CO}_{2}$ consumption. Environ Earth Sci 74(3):2369-2379. https://doi.org/10.1007/s12665-015-4237-6

Krishnaswami S, Singh SK (1998) Silicate and carbonate weathering in the drainage basins of the Ganga-Ghaghara-Indus head waters: contributions to major ion and Sr Isotope geochemistry. Proc Indian Acad Sci Earth Planet Sci 107(4):283-291. https://doi.org/10.1007/BF02841595

Krishnaswami S, Singh SK (2005) Chemical weathering in the River Basins of the Himalaya, India. Curr Sci 89(5):841-849

Krishnaswami S, Singh SK, Dalai T (1999) Silicate weathering in the Himalaya: role in contributing to major ions and radiogenic Sr to the Bay of Bengal. In: Somayajulu BLK (ed) Ocean science, trends $\&$ future directions. Indian National Science Academy and Academia International, New Delhi, pp 23-51

Liu WX, Sun Z, Zhao H, Shi T, Liu C, Taoze. (2018) Geochemistry of the dissolved loads during highflow season of rivers in the Southeastern Coastal Region of China: anthropogenic impact on chemical weathering and carbon sequestration. Biogeosciences 15(16):4955-4971. https://doi.org/10. 5194/bg-2018-109

Meybeck M (1987) Global chemical weathering of surficial rocks estimated from river dissolved loads. Am J Sci 287(5):401-428. https://doi.org/10.2475/ajs.287.5.401

Millot R, Gaillardet J, Dupré B, Allègre CJ (2002) The global control of silicate weathering rates and the coupling with physical erosion: new insights from rivers of the Canadian Shield. Earth Planet Sci Lett 196(1-2):83-98. https://doi.org/10.1016/S0012-821X(01)00599-4

Millot R, Gaillardet J, Dupré B, Allégre CJ (2003) Northern latitude chemical weathering rates: clues from the Mackenzie River Basin, Canada. Geochim Cosmochim Acta 67(7):1305-1329. https://doi. org/10.1016/S0016-7037(02)01207-3 
Moon S, Huh Y, Qin J, van Pho N (2007) Chemical weathering in the Hong (Red) River Basin: rates of silicate weathering and their controlling factors. Geochim Cosmochim Acta 71(6):1411-1430. https://doi.org/10.1016/j.gca.2006.12.004

Oliva P, Viers J, Dupré B (2003) Chemical weathering in granitic environments. Chem Geol 202(34):225-256. https://doi.org/10.1016/j.chemgeo.2002.08.001

Pacheco F, Van der Weijden CH (1996) Contributions of water-rock interactions to the composition of groundwaters in areas with a sizeable anthropogenic input: a case study of the water of the Fundao area, central Portugal. Water Resour Res 32:3553-3570. https://doi.org/10.1029/96WR01683

Patel P, Raju NJ, Subramanian V, Gossel W, Wycisk P (2020) Chemical weathering and atmospheric $\mathrm{CO}_{2}$ consumption in the Semi-Arid Swarnamukhi Basin (Peninsular India) estimated from river water geochemistry. Appl Geochem 113:104520. https://doi.org/10.1016/j.apgeochem.2020.104520

Pattanaik JK, Balakrishnan S, Bhutani R, Singh P (2013) Estimation of weathering rates and $\mathrm{CO}_{2}$ drawdown based on solute load: significance of granulites and gneisses dominated weathering in the Kaveri River Basin, Southern India. Geochim Cosmochim Acta 121:611-636. https://doi.org/10.1016/j.gca.2013. 08.002

Reddy SKK, Gupta H, Reddy DV (2019) Dissolved inorganic carbon export by mountainous tropical rivers of the Western Ghats, India. Chem Geol 530:119316. https://doi.org/10.1016/j.chemgeo.2019.119316

Sarin MM, Krishnaswami S, Dilli K, Somayajulu BLK, Moore WS (1989) Major ion chemistry of the Ganga-Brahmaputra river system: Weathering processes and fluxes to the Bay of Bengal. Geochimica et Cosmochimica Acta 53(5):997-1009

Sharif MU, Davis RK, Steele KF, Kim B, Kresse TM, Fazio JA (2008) Inverse geochemical modeling of groundwater evolution with emphasis on arsenic in the Mississippi River Valley alluvial aquifer, Arkansas (USA). J Hydrol 350(1-2):41-55

Sharma SK, Subramanian V (2008) Hydrochemistry of the Narmada and Tapti Rivers, India. Hydrol Process 22(17):3444-3455

Shin WJ, Ryu JS, Park Y, Lee KS (2011) Chemical weathering and associated $\mathrm{CO}_{2}$ consumption in six major river basins, South Korea. Geomorphology 129(3-4):334-341. https://doi.org/10.1016/j.geomo rph.2011.02.028

Stallard RF, Edmond JM (1981) Geochemistry of the Amazon precipitation chemistry and the marine contribution to the dissolved load at the time of peak discharge. J Geophys Res 86(10):9844-9858. https:// doi.org/10.1029/JC086iC10p09844

Stallard RF, Edmond JM (1983) Geochemistry of the Amazon: 2. The influence of geology and weathering environment on the dissolved load. J Geophys Res 88:9671-9688. https://doi.org/10.1029/JC088iC14p 09671

Sun HH, Li J, Zhang D, Shurong Lu, Xixi (2010) Science of the total environment chemical weathering inferred from riverine water chemistry in the lower Xijiang. Sci Total Environ 408(20):4749-4760. https://doi.org/10.1016/j.scitotenv.2010.06.007

Thomas J, Joseph S, Thrivikramji KP, Manjusree TM, Arunkumar KS (2014) Seasonal variation in major ion chemistry of a Tropical Mountain River, the Southern Western Ghats, Kerala, India. Environ Earth Sci 71(5):2333-2351. https://doi.org/10.1007/s12665-013-2634-2

Thomas J, Joseph S, Thrivikramji KP (2015) Hydrochemical variations of a Tropical Mountain River system in a rain shadow region of the Southern Western Ghats, Kerala, India. Appl Geochem 63:456-471. https://doi.org/10.1016/j.apgeochem.2015.03.018

Varol M, Gökot B, Bekleyen A, Şen B (2013) Geochemistry of the Tigris River Basin, Turkey: spatial \& seasonal variations of major ion compositions and their controlling factors. Quatern Int 304:22-32. https://doi.org/10.1016/j.quaint.2012.12.043

Wu W, Yang J, Shijin Xu, Yin H (2008) Geochemistry of the headwaters of the Yangtze River, Tongtian He and Jinsha Jiang: silicate weathering and $\mathrm{CO}_{2}$ consumption. Appl Geochem 23(12):3712-3727. https:// doi.org/10.1016/j.apgeochem.2008.09.005

Zhang J, Huang WW, Létolle R, Jusserand C (1995) Major element chemistry of the Huanghe (Yellow River), China-weathering processes and chemical fluxes. J Hydrol 168(1-4):173-203. https://doi.org/ 10.1016/0022-1694(94)02635-O

Publisher's Note Springer Nature remains neutral with regard to jurisdictional claims in published maps and institutional affiliations. 